GEOLOGICAL SURVEY CIRCULAR 104

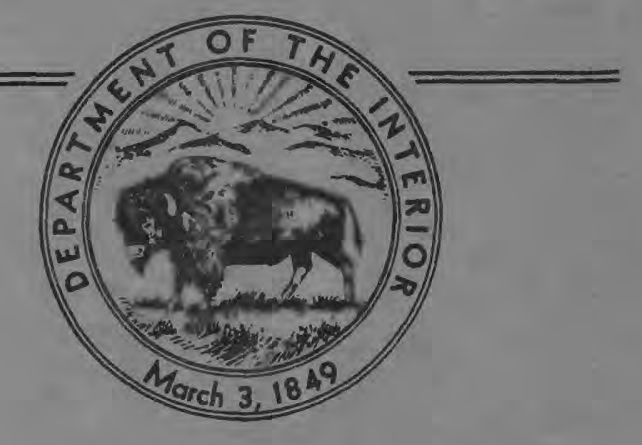

April 1951

\title{
WATER RESOURCES OF SOUTHEASTERN BUCKS COUNTY, PENNSYLVANIA
}

By

Jack B. Graham, John W. Mangan, and Walter F. White, Jr. 


\section{UNITED STATES DEPARTMENT OF THE INTERIOR \\ Oscar L. Chapman, Secretary \\ GEOLOGICAL SURVEY \\ W. E. Wrather, Director}

Washington, D. C.

Free on application to the Gealogical Survey, Washington 25, D. C. 


\section{WATER RESOURCES OF SOUTHEASTERN BUCKS COUNTY, PENNSYLVANIA}

By Jack B. Graham, John W. Mangan, and Walter F. White, Jr.

CONTENTS

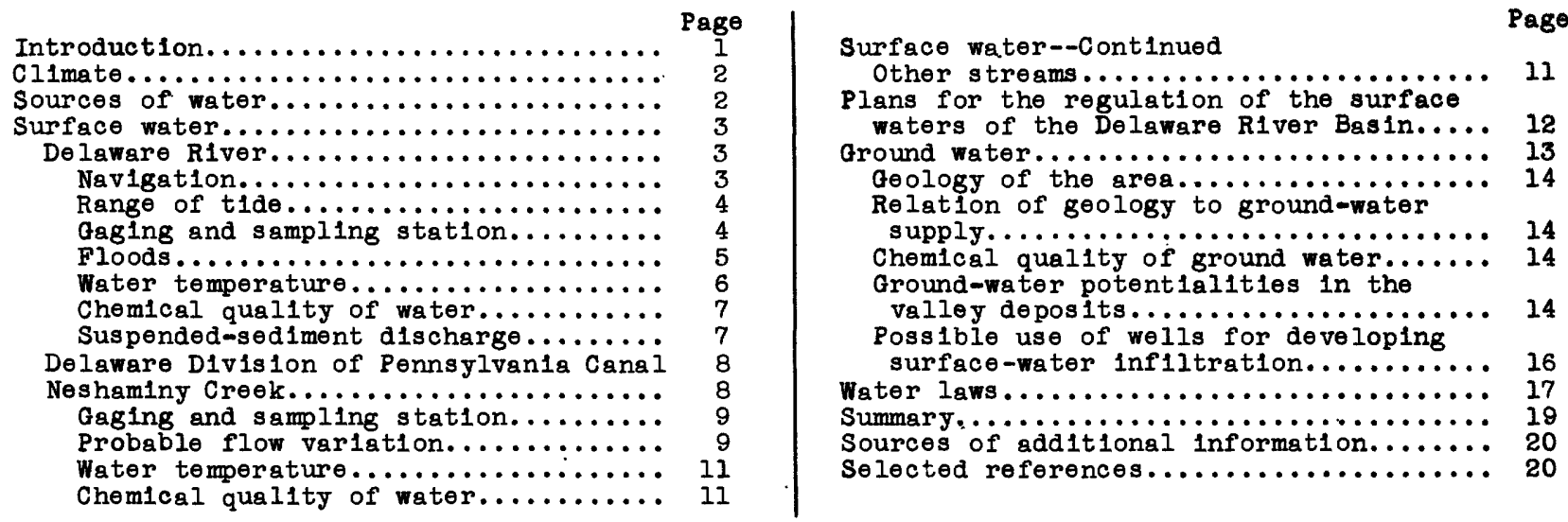

\section{ILLUSTRATIONS}

Plate 1. Map showing water resources of southeastern Bucks County, Pa. (In pocket)

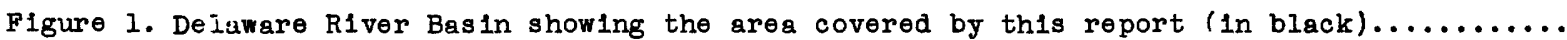

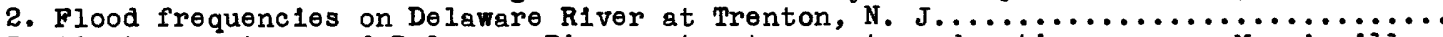

3. Alr temperature and Delaware River water temperature duration curves, Morrisville,

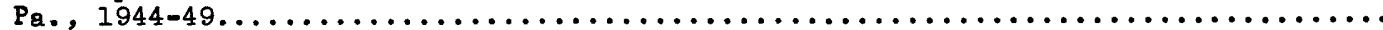

4. Dissolved-solids duration curve, Delaware River at Morrisvilie, Pa., 1944-49......

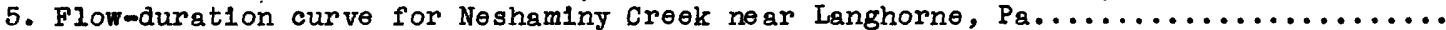

6. Discharge available without storage in Neshaminy Creok near Langhorne, Pa.........

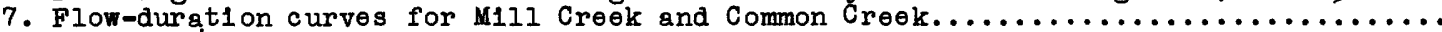

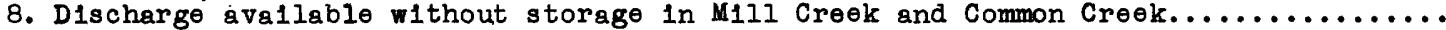

9. Areas of $h 1 g h$ and low ground-water yleld and areas of heavy pumping.............

10. North-south geologic section from Morrisville, Pa., to the Delaware River near

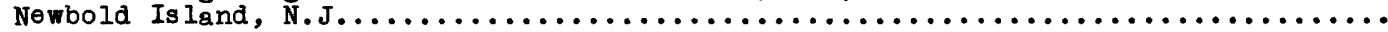

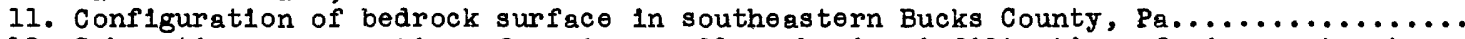

12. Schematic cross section of a river valley showing infiltration of river water to a

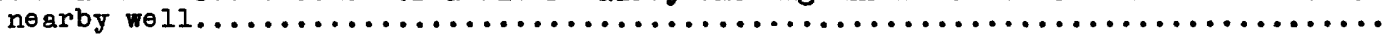

Page

12

TABLES

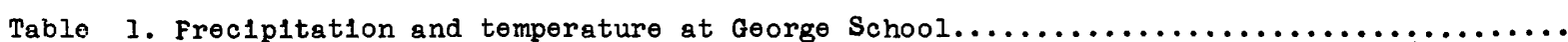

2. Average monthly and annual discharge or Delaware River at Trenton, N. J. (Morris-

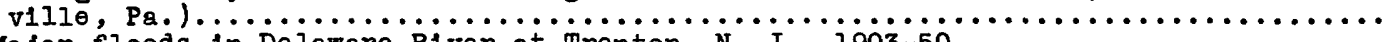

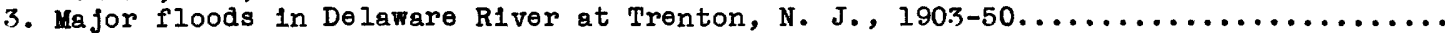

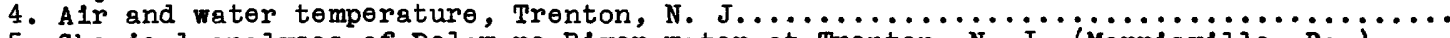

5. Chemical analyses of Delaware River water at Trenton, $\mathrm{N}$. J. (Morrisvilio, $\ddot{P a}_{i}$ ),

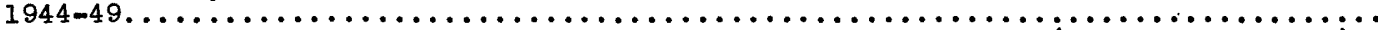

6. Suspended-sediment discharge, Delaware River at Trenton, $N$. J, (Morrisvilie, $P a$. ),

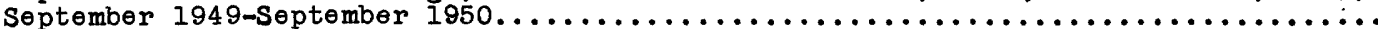

7. Average monthly and annual discharge of Neshaminy Creok near Langhorne, $\mathrm{P}_{2} \ldots \ldots \ldots . .$.

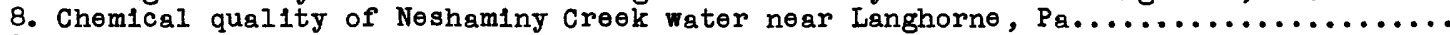

9. Chemical quality of the waters of small streams in southeastern Bucks County, Pa...

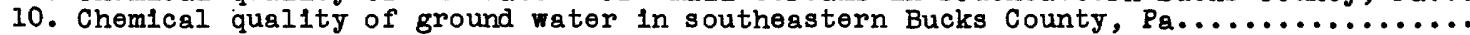




\section{INTRODUCTION}

This report has been prepared as a contribution to the development of southeastern Bucks County, Pa. It summarizes avaliable information on the water resources of this 90-square m1le area an evaluates current supplies. Future development of the area may change both the available quantity and the quality of the water supply. The effective development of the area demands a continuing knowledge of the water used and the potential quantity and quality of water avallabje from both underground and surface sources.

The area is strateglcally important to a great Industrial section of the Bast. Its eastern boundary is a 26-mile segment of the Delaware River along the extreme southeastern border of Bucks County, $\mathrm{Pa}$. ( $\mathrm{flg}$. 1). The present. population of the area is about 40,000 , including 24,800 in Bristol Borough and Township and 6,770 in Morris ville. The area is traversed by both the Pennsylvania and the Reading Ra11roads and $a 180$ by U.S. Highways 1 and 13 . These are main transportation routes connecting the great marke t outlets of Phlladelphla and New York. The Delaware River'is navigable from Morrisville to the sea. The area is only a short distance upstream from the Port of Ph1ladelphia, whlch ranks second only to New York as the most Important seaport in the United States.

The area is mostly flat, open land 10 to 60 feet above mean sea level. It contains several large industries, concentrated chlefly in the Bristol area (pl. 1). There are also scattered industries in the Morrisville, Langhorne, and Bensalem areas. However, Bucks County retains some of the characteristics of a farming reglor. Truck farming and gardening are still carried on to a considerable extent. Along Delaware River below Morrisville the mining of sand and gravel is an important industry.

The facts summarized in this report have been accumulated over $a$ period of 25 years or more by Federal, State, and local agencies in con- nection with investigations for other purposes. Most of the date used in this report have been obtained by the United States Ceological Survey In cooperation with the Pennsylvanie Department of Forests and Faters, the Pennsylvania Department of Internal Affairs, the Pennsylvania Department of Commerce, and State Planning Board, the C1ty of Philadelphia, the Corps of Engineers, and the Interstate Commision on the Delaware River Basin.

Th1s report was prepared in the Water Resources DIvision of the U.S.Ceologioal Survey by Jack B. Graham, District Goolog1st; John W. Mangan, District Engineer; and Waiter F. White, Jr., District Chemist, under the seneral direction of C. G. Paulsen, Chief Hydraulic Engineer.

\section{CITIATM}

Southeastern Bucks County probably has the mildest climate of any area in the commonwealth. It is in the eastern coastal belt and has a typ1cal maritime climate. Precipitation averages about the same as for Pennsylvania as a whole and is evenly distributed throughout the year. Snow is uncommon before December and after early Apr1l. Snow cover may be expected for a total of less than 30 days in any normal jear. Hurr1canes and tornadoes, although rere, are not unknown. Once every four or five winters $a$ severe glaze storm will occur. Owing to proximity of the ocean, the area has relatively high humidity, averaging about 57 percent for the year. No extremely high or low temperatures occur. For only about one day. in the average year is a temperature of $0^{\circ} \mathrm{F}$. recorded, and the temperature in summer very rarely will rise to $100^{\circ} \mathrm{F}$.

The United States Weather Bureau has maintained a precipitation-temperature station at George School for the past 41 years. George School is 2 miles north of Langhorne and just outside the northwest map boundary of plate 1 . It is believed that the following records for George School are representative of the cond1tions of the area.

Table 1.--Precipitation and temperature at George school

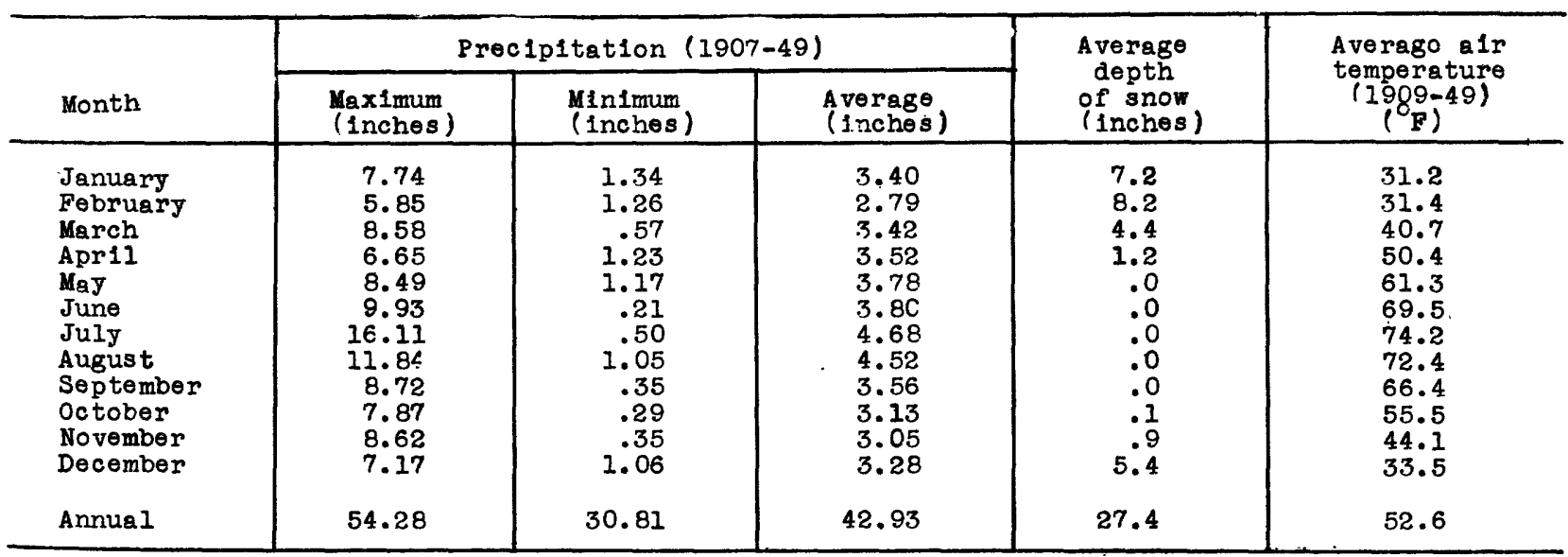

SOURCES OF WATER

Precipitation is the common source of essentially all the water contained on the surface or underground. During a typical rain some water runs over the land surface and immediately becomes part of the flow of small streams and of the Delaware River. Part of the water re- mains on the surface of plants and on the ground and is subsequentiy evaporated. St1ll another part enters the soll where it is held for a time and later is used by plants in the process of transpiration. Finally, that part of the rain not thus disposed of seeps deeper through the so11, reaching the ground-water zone. It then hegins its slow lateral movement to out- 


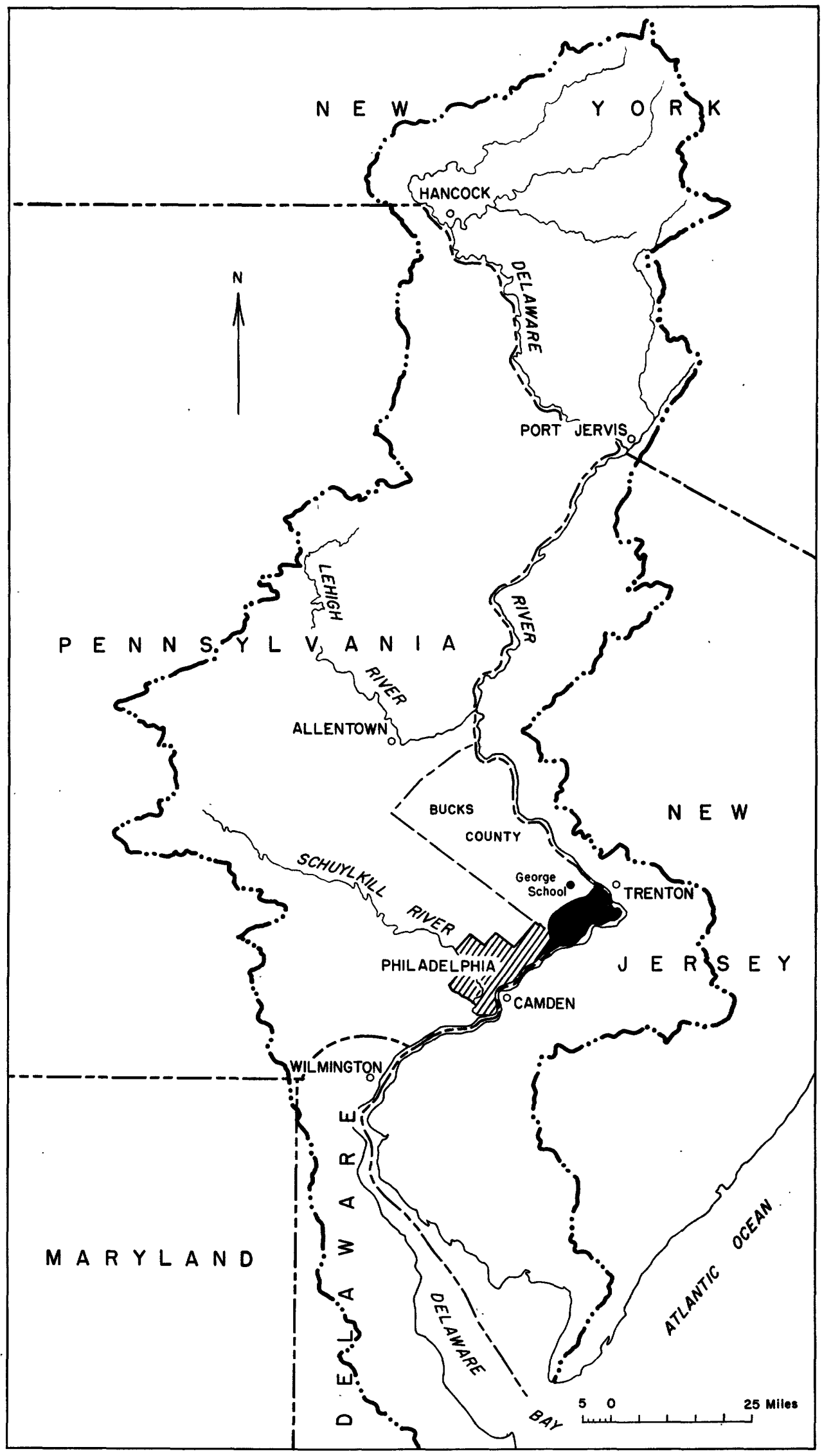

Figure 1.--Delaware River Basin showing the area covered by this report (in black) 
lets in streams, springs, and wells. It is the continued discharge of this ground-water storage that keeps creeks and rivers from dry ing up during prolonged rainless periods. Thus, the surface-water and ground-water resources of southeastern Bucks County, as of most other areas, are very closely interrelated.

The principal sources of water of southeastern Bucks County are the Delaware River, Neshaminy, Poquessing, M111, and Common Creeks; several small ponds and lakes (pl.1); and ground water. Obviously, (f1g.1) ilttle of the flow of the Delaware River in the MorrisvilieBristol area is derived from the nearby area; most of it comes from the upper basin. The Delaware River as it passes the area acts primarily as a conduit for waters coming from other reglons. The flow of the river and the chem1cal character of the water, therefore, are controlled in large part by factors beyond local influences. However, nearly all the other water sources mentioned are closely related to local environmental factors. Almost all the Neshaminy Creek Basin lies within. Bucks County, and the basins of both 4111 and Common creeks are entirely within the area covered by this report. Poquessing Creek drainage extends a few miles beyond the southwestern limit of the area. It is probable that essentially all the ground water in southeastern Bucks County comes from precipitation falling within the area. Contrary to a popular belief, the water flowing from the springs and pumped from wells does not come from the Pocono Mountains nor from the upper Deleware Basin. It results from the infiltration of local storm water.

\section{SURPACE - WATER}

Surface water avallable within the area of this report is sufficient for all present uses and for all foreseeable future uses. The minimum flow of the Delaware River as it enters the area is many times the present demand of 30 to 35 million gallons a day. In fact, the flow is so great and the river so accessible that, with the exception of Neshaminy Creek, development of the small tributaries within the area is not likely to be economical so long as the flow of the river is maintained and no serious problems of quality are introduced. The various uses of water upstream and across the river in the Trenton N. J., area are not likely to change this situation.

The quality of water throughout the area is generally favorable for most uses without costif treatment. Although waste-disposal practices in recent jears have threatened the water supply of the entire lower Delaware Basin, corrective measures are proving effective in reducing pallution. As in most surface waters, the chemical character of the water in the streams in the area varies in response to precipitation and to the varlable effect of the soll, vegetation, topography, and use of water in the dralnage basin. The Delaware River, and the smaller streams in the area have about the same chemical quality, except where affected by industrial or domestic pollution. In the zone along the river, pollution and ground-water inflow tend to alter the chemical characteristics of smaller streams. In general, however, the chemical quality of most of the surface waters can be expected to be as indicated by the range of concentrations given below.
Parts per m1liton (except pH)

Dissolved solids..... Hardness (as $\mathrm{CaCO}_{3}$ ).. Bicarbonate.........

Sulfate............ Chloride.............

Fluoride...........

Nitrate.............

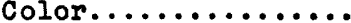

Iron..............

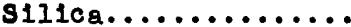

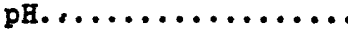
50-150
30-120
10-70
$15-50$
$1-10$
$.0-.3$
$1-15$
5-30
$.05-.3$
$1-15$
6. $0-8.0$

In only a few places have major departures from these ranges been noted. These are princlpally in the industrialized areas near Morrisvilie and Bristol and in the lower sections of small streams near the Delaware River. Ho Ind lcation of salinity has been found in the Delavare River or its tributaries in the area covered by this report.

Sediment in the water is not a major problem in southeastern Bucks County. No records are avallable to show the amount of suspended sediment transported during periods of high runoff. A sediment station on the Delaware River at Morris ville has been in operation only since September 1949. The maximum sediment concentration measured was 550 parts per million (ppm), and for long periods of time the sediment concentration remained below 15 to 20 parts per mililon. It has been as low as 1 part per million many times.

Surface-water temperatures in the region can be expected to range from $32^{\circ} \mathrm{F}$. to nearly $90^{\circ}$ F., the monthly mean water temperature being about the same as the monthly mean alr temperature.

\section{Delaware River}

The Delaware River has a drainage area of 6,780 square miles and a length of about 160 miles about Korrisville, $\mathrm{Pa}$. This area lies in New York, New Jersey, and Pennsylvania. In parts of its course the river serves as the boundary between states. From Yorrisville it flows southeast to Bordentown, then generally southwest beyond the area of this report. The channel is broad, having low banks and many low is lands. The river averages about 1,000 feet in width at Morrisville and broadens somewhat downstream.

of the 42 inches of precipitation falling on the watershed of the Delaware River above Morrisville in any normal year, about 24 inches, or slightiy more than half of the original precipitation, enters the Delaware River--directly or after having passed through the ground-- and f1nally runs off to the sea. The remaining 18 inches is evaporated.from ground and water surfaces or transpired by vegetation.

Navigation:-- The Delaware River is navigable from Trenton, iN. J., to the sea. Congress has authorized a ship channel having a minimum depth of 25 feet and a width of about 300 feet between Allegheny Avenue in Philadelphia and the Marine Terminal at Trenton. However, surveys in June 1949 Indicate that depths are considerably less thap 25 feet in most channel ranges at the present time. Detalled information concerning depths, widths, ranges, and anchorages can be obtained from the Corps of Engineers, Philadelphia, Pa. 
Table 2.-Average monthly and annual discharge of Delaware River at Trenton, N.J. (Morrisville, Pa.)

(Cubic reet per second)

[These figures include diversion above the gage in the Delaware and Raritan Canal, Delaware Division of the Pennsylvania Canal, and the Trenton power race.except when it is returned to the river above the gage. They have been adjusted for change in contents in Lakes Hopatcong and Wallenpauback and in Toronto, Cliff Lakes, and Swinging Bridge Reservoirs. They therefore indicate approxImately the natural flow that would have occurred if these developments had not been in operat1on. In recent jears the diversions in the Delaware and Raritan Canal and in the Delaware Division of the Pennsylvania Canal have been small, the sum of mean annual diversions ranging between 10 and $35 \mathrm{cfs}$. At the present time, water diverted to the Trenton power race is returned to the river above the gage.]

\begin{tabular}{|c|c|c|c|c|c|c|c|c|c|c|c|c|c|}
\hline Year. & oct. & Nov. & Dec. & Jan. & Feb. & Mar. & Apr. & May & June & July & Aug. & Sept. & Annua 1 \\
\hline $\begin{array}{l}1913 \\
1913-14 \\
1914-15 \\
1915-16 \\
1916-17\end{array}$ & $\begin{array}{l}3, \overline{860} \\
2,030 \\
5,540 \\
3,500\end{array}$ & $\begin{array}{r}- \\
11,600 \\
2,290 \\
6,080 \\
3,460\end{array}$ & $\begin{array}{r}- \\
10,200 \\
4,080 \\
10,800 \\
8,390\end{array}$ & $\begin{array}{r}7,600 \\
23,400 \\
15,600 \\
12,600\end{array}$ & $\begin{array}{r}- \\
12,500 \\
23,300 \\
14,100 \\
5,740\end{array}$ & $\begin{array}{l}30,200 \\
20,400 \\
11,300 \\
13,100 \\
21,800\end{array}$ & $\begin{array}{l}24,700 \\
33,700 \\
12,300 \\
36,200 \\
18,500\end{array}$ & $\begin{array}{r}11,600 \\
16,000 \\
8,980 \\
11,200 \\
8,710\end{array}$ & $\begin{array}{r}6,790 \\
5,240 \\
5,910 \\
11,800 \\
16,900\end{array}$ & $\begin{array}{r}2,940 \\
5,900 \\
8,550 \\
10,300 \\
\theta, 170\end{array}$ & $\begin{array}{r}3,100 \\
4,470 \\
12,300 \\
5,190 \\
5,710\end{array}$ & $\begin{array}{l}2,590 \\
3,200 \\
6,980 \\
3,490 \\
3,630\end{array}$ & $\begin{array}{r}11,300 \\
9,980 \\
11,900 \\
9,870\end{array}$ \\
\hline $\begin{array}{l}1917-18 \\
1918-19 \\
1919-20 \\
1920-21 \\
1921-22\end{array}$ & $\begin{array}{r}5,020 \\
4,400 \\
5,520 \\
10,700 \\
3,330\end{array}$ & $\begin{array}{r}11,300 \\
5,120 \\
18,000 \\
13,400 \\
10,100\end{array}$ & $\begin{array}{r}4,130 \\
8,700 \\
13,400 \\
23,600 \\
16,000\end{array}$ & $\begin{array}{r}4,620 \\
13,000 \\
5,200 \\
10,500 \\
5,590\end{array}$ & $\begin{array}{r}20,000 \\
7,800 \\
3,410 \\
7,640 \\
11,500\end{array}$ & $\begin{array}{l}26,500 \\
22,900 \\
35,900 \\
33,100 \\
28,100\end{array}$ & $\begin{array}{l}20,700 \\
19,400 \\
27,600 \\
17,100 \\
24,200\end{array}$ & $\begin{array}{l}10,800 \\
17,400 \\
11,200 \\
13,300 \\
12,000\end{array}$ & $\begin{array}{r}7,630 \\
6,120 \\
7,390 \\
3,980 \\
16,300\end{array}$ & $\begin{array}{r}3,350 \\
10,600 \\
10,100 \\
5,790 \\
9,480\end{array}$ & $\begin{array}{l}2,690 \\
8,740 \\
9,070 \\
4,100 \\
4,180\end{array}$ & $\begin{array}{l}-3,230 \\
5,300 \\
7,040 \\
2,800 \\
4,190\end{array}$ & $\begin{array}{r}9,900 \\
10,800 \\
12,800 \\
12,200 \\
12,100\end{array}$ \\
\hline $\begin{array}{l}1922-23 \\
1923-24 \\
1924-25 \\
1925-26 \\
1926-27\end{array}$ & $\begin{array}{r}2,990 \\
4,010 \\
15,900 \\
5,410 \\
10,500\end{array}$ & $\begin{array}{r}2,290 \\
4,700 \\
4,050 \\
16,200 \\
25,400\end{array}$ & $\begin{array}{r}2,410 \\
15,900 \\
6,470 \\
14,300 \\
10,100\end{array}$ & $\begin{array}{r}8,780 \\
20,500 \\
3,600 \\
8,890 \\
11,500\end{array}$ & $\begin{array}{r}6,220 \\
7,870 \\
27,600 \\
13,200 \\
15,200\end{array}$ & $\begin{array}{l}28,400 \\
11,600 \\
17,500 \\
19,000 \\
27,400\end{array}$ & $\begin{array}{l}19,600 \\
32,600 \\
12,900 \\
20,500 \\
11,800\end{array}$ & $\begin{array}{r}15,000 \\
21,300 \\
10,400 \\
7,370 \\
16,300\end{array}$ & & $\begin{array}{l}2,710 \\
5,280 \\
6,150 \\
2,820 \\
5,550\end{array}$ & $\begin{array}{l}2,560 \\
2,850 \\
6,490 \\
6,870 \\
9,040\end{array}$ & $\begin{array}{r}3,220 \\
2,850 \\
5,980 \\
6,400 \\
10,400\end{array}$ & $\begin{array}{r}8,290 \\
11,400 \\
10,000 \\
10,500 \\
13,500\end{array}$ \\
\hline $\begin{array}{l}1927-28 \\
1928-29 \\
1929-30 \\
1930-31 ! \\
1931-32\end{array}$ & $\begin{array}{r}24,600 \\
4,620 \\
8,170 \\
1,610 \\
1,750\end{array}$ & $\begin{array}{r}27,700 \\
3,920 \\
11,200 \\
2,420 \\
1,950\end{array}$ & $\begin{array}{r}29,100 \\
5,1.30 \\
12,400 \\
3,160 \\
4,980\end{array}$ & $\begin{array}{r}12,600 \\
8,210 \\
12,800 \\
3,730 \\
13,800\end{array}$ & $\mid \begin{array}{r}18,000 \\
9,070 \\
12,400 \\
5,270 \\
13,500\end{array}$ & $\begin{array}{l}13,900 \\
27,700 \\
20,500 \\
14,200 \\
10,500\end{array}$ & $\begin{array}{l}25,100 \\
30,100 \\
14,900 \\
21,800 \\
25,000\end{array}$ & $\begin{array}{r}19,800 \\
18,700 \\
7,750 \\
16,600 \\
10,600\end{array}$ & $\begin{array}{r}20,200 \\
6,450 \\
9,500 \\
9,460 \\
7,670\end{array}$ & $\begin{array}{r}2.3,900 \\
4,040 \\
4,100 \\
11,800 \\
4,200\end{array}$ & $\begin{array}{r}1.3,800 \\
3,290 \\
1,930 \\
4,050 \\
2,280\end{array}$ & $\begin{array}{l}200 \\
850 \\
240 \\
770 \\
440\end{array}$ & $\begin{array}{r}19,900 \\
10,400 \\
9,810 \\
8,090 \\
8,100\end{array}$ \\
\hline $\begin{array}{l}1932-33 \\
1933-34 \\
1934-35 \\
1935-36 \\
1936-37\end{array}$ & $\begin{array}{r}10,200 \\
7,827 \\
10,870 \\
2,970 \\
3,663\end{array}$ & $\begin{array}{r}27,300 \\
6,855 \\
11,200 \\
22,500 \\
7,094\end{array}$ & $\begin{array}{r}8,550 \\
8,037 \\
20,440 \\
14,360 \\
13,780\end{array}$ & $\begin{array}{l}10,300 \\
15,540 \\
14,190 \\
14,570 \\
25,080\end{array}$ & $\begin{array}{r}11,100 \\
5,214 \\
9,475 \\
7,252 \\
18,980\end{array}$ & $\begin{array}{l}21,700 \\
15,190 \\
22,670 \\
63,290 \\
12,390\end{array}$ & $\begin{array}{l}30, \\
25, \\
14, \\
26, \\
26,\end{array}$ & $\begin{array}{r}10,900 \\
11,930 \\
11,490 \\
8,606 \\
15,920\end{array}$ & $\begin{array}{l}5,130 \\
6,214 \\
5,239 \\
6,694 \\
9,710\end{array}$ & $\begin{array}{r}3,460 \\
4,600 \\
17,370 \\
2,808 \\
6,154\end{array}$ & $\begin{array}{r}19,500 \\
3,589 \\
4,374 \\
2,938 \\
6,948\end{array}$ & $\begin{array}{r}22,700 \\
11,520 \\
4,307 \\
2,494 \\
5,415\end{array}$ & $\begin{array}{l}15,100 \\
10,210 \\
12,260 \\
14,610 \\
12,570\end{array}$ \\
\hline $\begin{array}{l}1937-38 \\
1938-39 \\
1939-40 \\
1940-41 \\
1941-42\end{array}$ & $\begin{array}{r}10,960 \\
7,845 \\
3,567 \\
3,889 \\
1,503\end{array}$ & $\begin{array}{r}13,800 \\
10,870 \\
7,620 \\
14,410 \\
3,175\end{array}$ & $\begin{array}{r}12,600 \\
26,140 \\
5,766 \\
14,660 \\
7,754\end{array}$ & $\begin{array}{r}14,580 \\
10,160 \\
4,515 \\
11,500 \\
8,285\end{array}$ & $\begin{array}{r}17,270 \\
24,970 \\
4,787 \\
9,478 \\
9,579\end{array}$ & $\begin{array}{l}15,270 \\
25,850 \\
18,900 \\
12,200 \\
23,630\end{array}$ & $\begin{array}{l}16,380 \\
27,970 \\
54,450 \\
22,620 \\
15,410\end{array}$ & $\begin{array}{r}9,304 \\
8,603 \\
16,040 \\
5,533 \\
20,470\end{array}$ & $\begin{array}{r}9,562 \\
3,901 \\
11,570 \\
5,011 \\
12,030\end{array}$ & $\begin{array}{r}18,220 \\
2,414 \\
5,377 \\
4,498 \\
5,769\end{array}$ & $\begin{array}{r}12,460 \\
2,395 \\
2,789 \\
3,855 \\
13,090\end{array}$ & $\begin{array}{l}8,580 \\
1,546 \\
9,618 \\
1,764 \\
1,120\end{array}$ & $\begin{array}{r}14,050 \\
12,640 \\
12,030 \\
9,095 \\
11,000\end{array}$ \\
\hline $\begin{array}{l}\overline{1} 942-43 \\
1943-44 \\
1944-45 \\
1945-46 \\
1946-47\end{array}$ & $\begin{array}{r}16,860 \\
5,175 \\
2,510 \\
12,940 \\
5,547\end{array}$ & $\begin{array}{r}16,850 \\
16,450 \\
4,583 \\
18,120 \\
4,307\end{array}$ & $\begin{array}{r}18,930 \\
4,821 \\
10,290 \\
14,960 \\
4,409\end{array}$ & $\begin{array}{r}18,530 \\
5,880 \\
9,948 \\
17,360 \\
12,680\end{array}$ & $\begin{array}{r}17,730 \\
6,732 \\
9,150 \\
7,147 \\
11,820\end{array}$ & $\begin{array}{l}26,100 \\
20,390 \\
38,720 \\
24,560 \\
19,820\end{array}$ & $\begin{array}{r}16,630 \\
24,840 \\
16,570 \\
8,446 \\
27,190\end{array}$ & $\begin{array}{l}24,890 \\
11,170 \\
20,290 \\
20,940 \\
31,180\end{array}$ & $\left|\begin{array}{r}11,910 \\
6,821 \\
14,300 \\
17,920 \\
14,030\end{array}\right|$ & $\begin{array}{r}4,170 \\
3,261 \\
25,660 \\
7,753 \\
19,990\end{array}$ & $\begin{array}{r}2,459 \\
2,036 \\
1.3,700 \\
5,131 \\
8,435\end{array}$ & $\begin{array}{r}1,672 \\
3,104 \\
12,160 \\
3,816 \\
4,332\end{array}$ & $\begin{array}{r}14,740 \\
9,197 \\
14,900 \\
13,320 \\
13,670\end{array}$ \\
\hline $\begin{array}{l}1947-48 \\
1948-49\end{array}$ & $\begin{array}{l}2,406 \\
2,296\end{array}$ & $\begin{array}{r}15,350 \\
6,039\end{array}$ & $\begin{array}{r}7,384 \\
11,240\end{array}$ & $\begin{array}{r}5,567 \\
33,390\end{array}$ & $\begin{array}{l}11,340 \\
19,470\end{array} \mid$ & $\begin{array}{l}35,650 \\
13,450\end{array}$ & $\begin{array}{l}26,650 \\
16,740\end{array}$ & $\begin{array}{l}22,590 \\
16,300\end{array}$ & $\begin{array}{r}13,120 \\
5,136\end{array}$ & $\begin{array}{l}7,552 \\
3,315\end{array}$ & $\begin{array}{l}5,226 \\
2,236\end{array}$ & $\begin{array}{l}2,264 \\
2,360\end{array}$ & $\begin{array}{l}12,920 \\
10,970\end{array}$ \\
\hline $\begin{array}{l}\text { Maximum } \\
\text { Minimum } \\
\text { Mean }\end{array}$ & $\begin{array}{r}24,600 \\
1,503 \\
6,514\end{array}$ & $\begin{array}{r}27,700 \\
1,950 \\
10,770\end{array}$ & $\begin{array}{r}29,100 \\
2,410 \\
11,320\end{array}$ & $\begin{array}{r}33,390 \\
3,600 \\
12,070\end{array}$ & $\left|\begin{array}{r}27,600 \\
3,410 \\
12,110\end{array}\right|$ & $\begin{array}{l}63,290 \\
10,500 \\
22,800\end{array}$ & $\begin{array}{r}54,450 \\
8,446 \\
22,880\end{array}$ & $\begin{array}{r}31,180 \\
5,53.3 \\
14,360\end{array}$ & $\begin{array}{r}20,200 \\
3,901 \\
8,962\end{array}$ & $\begin{array}{r}25,660 \\
2,414 \\
7,814\end{array}$ & $\begin{array}{r}19,500 \\
1,930 \\
6,051\end{array}$ & $\begin{array}{r}22,700 \\
1,440 \\
5,691\end{array}$ & $\begin{array}{r}19,900 \\
8,090 \\
11,780\end{array}$ \\
\hline
\end{tabular}

Range of tide:-- The head of tidewater is at the Pennsylvania Railroad bridge at Trenton Falls. Below Trenton and at Bordentown the mean monthly range in tide is 6.7 feet and at $\mathrm{Phila}-$ delphia, 6.0 feet. Varlations in the tidal range are caused principaliy by the seasonal change in the fresh-water inflow. The effect of fresh-water flow on the range in tide along the estuary decreases downstream.

Salinity:-- Salinity has never been a problem in this area. Even during the extreme drought period in 1931-32, salt. Water from the sea was never recorded above the Philadelphia-Bucks County line. During years of normal summer flow. the salinity front in Delaware River does not advance nearer than 25 to 30 miles below Bristol.

Gaging and Sampling Station:-- A continuous record of the stage and flow of the Delaware River has been obtained at the Calhoun Street Bridge at Trenton, N. J., since February 1913. The datum of the page is 7.77 feet above mean sea level, datum of 1929. In recent years records have also included chemical quality, temperature, and suspended-sediment discharge. Daily 


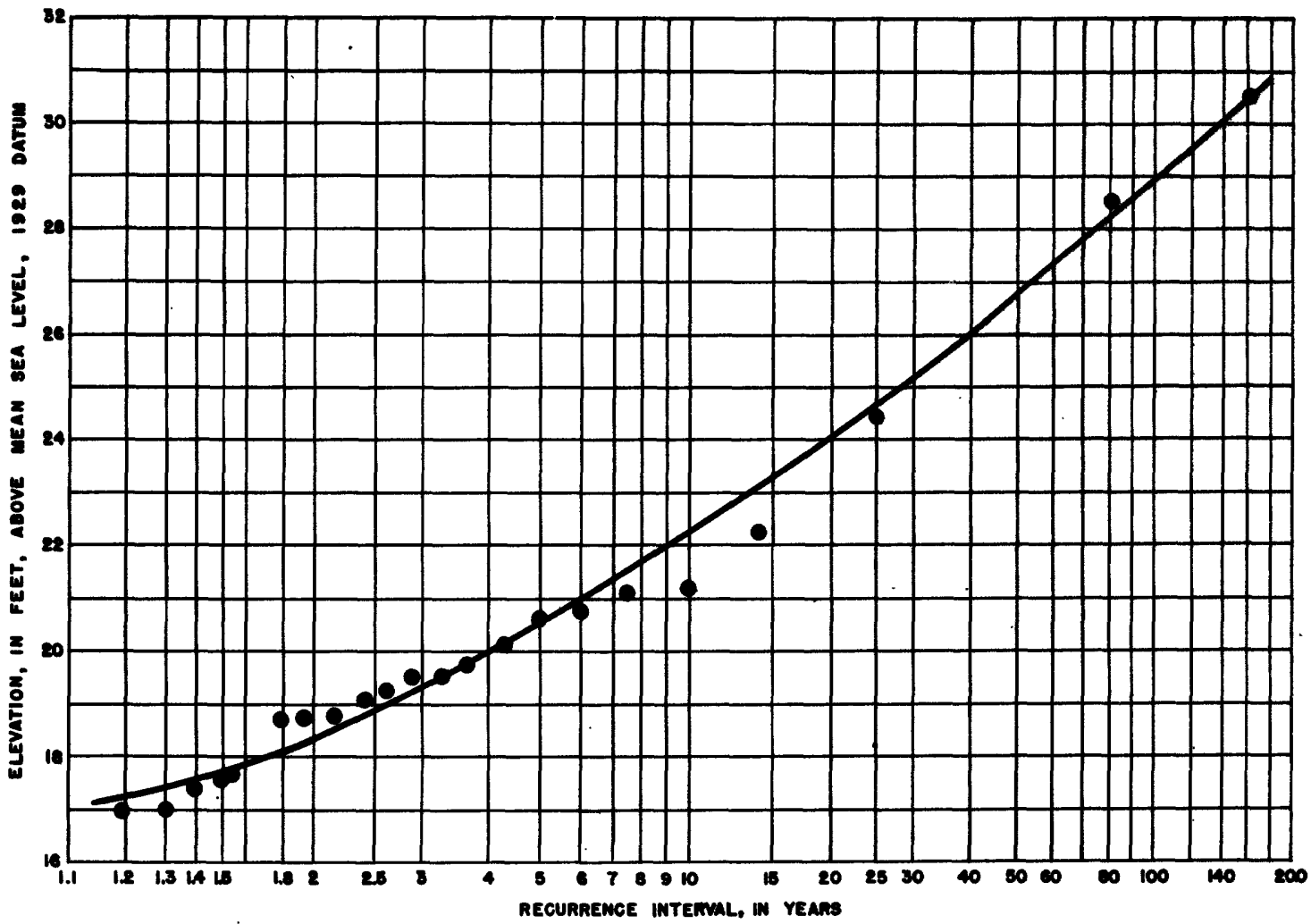

Figure 2.--Flood frequencies on Delaware River at Trenton, N. J.

records of chemical quality and water temperature are available from October 1944 to date. Records of suspended-sediment discharge date from September 1949.

Pertinent hydrologic data colleoted at the Trenton station follow:

Drainage area: 6,780 square miles.

Average discharge $(1913-49)=$.36 jears, 11,780 cublc feet per second 1 (including actual flow at the gage plus diversion past the gage in the Delaware and Raritan Canal, Delaware Division of the Pennsylvania Canal, and the Trenton power race).

Monthly discharge: Monthly mean discharge for the period 1913-49 is given in table 2 .

Minimum aischarge (1913-49) 1,220 cfs, Sept. $18,19,1932$ (not including approximately 150 cfs diverted in the Trenton power race and the Delaware and Raritan Canal); minimum gage height 0.43 foot, Sept. 30, 1943.

Floods:-- Records of floods in the lower Delaware River go back to october 1786. The greatest flood in this period of 164 years was that of October 1903. The flood caused the Inundation of considerable land along the river. From a

1 In many Geological Survey reports the term second-feet is used in place of cubic feet per second. One cublc foot per second (cfs) equals 0.646 million gallons per day (mga).

hyarologic point of view the flood of october 1903 is considered outstanding. However, it cannot be considered so gieat that it will not recur within this generation. A similar or even greater flood, probably aggravated by stormraised tides, is easily possible. This shoula be borne in mind when permanent developments are being planned in the area.

Crest elevations, in feet above mean sea level (ms l), Sandy Hook datum, of the flood of octoker 11, 1903, from Scudders Falls, N. J., to Philadelphia, Pa., follow:

Miles

below

Scudders

Falls

0.0 Scudders Falls, N. J.; Bunga low Colony

1.6 Yardiey, Pa.; highway bridge

5.2 Morrisville; Pa.; 465 N. Delmarr St.

8.9 Upper end of Duck Is land at cana 1

11.0 Bordentown, N. J.; Crosswicks Creek

13.3 Newbold Is land; Potters House

17.0 Florence, N. J.

20.1 Bristol, $\mathrm{Pa}$.

21.3 Burlington, N. J.; waterworks

39.0 Philadelphia, Pa.; Race Street
Crest

elevation

feet above ms I)

44.4

39.1

27.8

18.8

17.5

16.1

13.6

10.1

9.7

7.5 
These are sufficient data for a profilo of the flood to be drawn for this strotch of the Delaware R1ver.

Crest helghts below Morrisville, Pa., were of focted by t1des. Furthermore, the records were doubtless obtalned a considerable distance back from the $r$ iver and in some instances may not represint the true crests. The records were obtained from private sources and furnished by the Corpa of Englneers, Philadelphia, $\mathrm{Pa}$.

The crest holghts, olovations, and discharges of all major floods (more than 20 foot above mean sea level) at Trenton, N. J., 1903-50, are Biven in tablo 3 .

The flood-frequeney ourve as glven in flgure 2 was developed from all known authent1o data collected at Trenton and from records of the - lovation of historlo floods that could bo referred to the Trenton gage datum. The ourve may bo used to estimate the probability of the recurrence of a flood of a certain magnitude. It should bo recognized that such est imates although based upon avallable experience cannot have a high degree of acouracy.

Veter temperature:-- During the 5-jear period ended sept. 30,1949 , the water temperature of the Delaware River at Trenton, N. J., was measured once each day. The maximum temperature observed was $88^{\circ} \mathrm{F}$. Temperatures near the freezIng point of water were found in the coldest parts of each pinter. The mean annual water temperature was $56^{\circ}$ F. --2 degrees higher than the mean annual air temperature at Trenton. Maximum, minimum, and average water temperatures ( $\left.{ }^{\mathrm{F} .}\right)$ and average a1r temperature (OF.) at Trenton, 194448, are given by months in table 4.

For the 5 jears onded sept. 30,1849 , the perm oentage of time during whioh the alr or water temperature at Trenton equaled or oxceeded any given temperature can be determined from the curves shom in figure 3 .

Tablo 3.--Major floods in Dolawaro River at Trenton, N. J., 1903-50

[age he1ght plus 7.77 equals mean gea lovel olovation, datum of 1829]

\begin{tabular}{|c|c|c|c|}
\hline Dato & $\begin{array}{l}\text { Gage } \\
\text { holght } \\
\text { (reot) }\end{array}$ & $\begin{array}{l}\text { Blevation } \\
\text { above ms } 1 \\
\text { (foet) }\end{array}$ & $\begin{array}{c}\text { D1soharge } \\
\text { (ofs) }\end{array}$ \\
\hline $\begin{array}{l}1803 \text {, Oct. } 11 \\
1804, \text { Mar. } 8 \\
1913 \text {, Mar. } 28 \\
1914, \text { Mar. } 28 \\
1924, \text { Oct. } 2 \\
1925 \text {, Fob. } 13 \\
1933, \text { Aug. } 25 \\
1934, \text { Mar. } 5 \\
1936 \text {, Jan. } 3 \\
1936, \text { Mar. } 13 \\
1936 \text {, Mar. } 19 \\
1940, \text { Apr. } 1 \\
1942, \text { May } 24\end{array}$ & $\begin{array}{l}20.79 / \\
22.8 \mathrm{~b} \\
13.3 \\
12.0 \\
12.5 \\
13.0 \\
12.66 \mathrm{~b} / \\
14.20 \mathrm{~b} / \\
16.12 \mathrm{~b} / \\
15.34 \\
16.66 \\
12.85 \\
13.35 .\end{array}$ & $\begin{array}{l}28.5 \mathrm{~d} / \\
30.6 \mathrm{~b} / \\
21.1 \\
18.8 \\
20.3 \\
20.8 \\
20.4 \\
22.0 \mathrm{~b} / \\
23.8 \mathrm{~b} / \\
23.1 \\
24.4 \\
20.6 \\
21.1\end{array}$ & $\begin{array}{c}295,0009 \\
160,000 \\
143,000 \\
144,000 \\
154,000 \\
146,000 \\
\cdots- \\
198,000 \\
227,000 \\
152,000 \\
161,000\end{array}$ \\
\hline
\end{tabular}

a/Estimated
b/Ice Jam

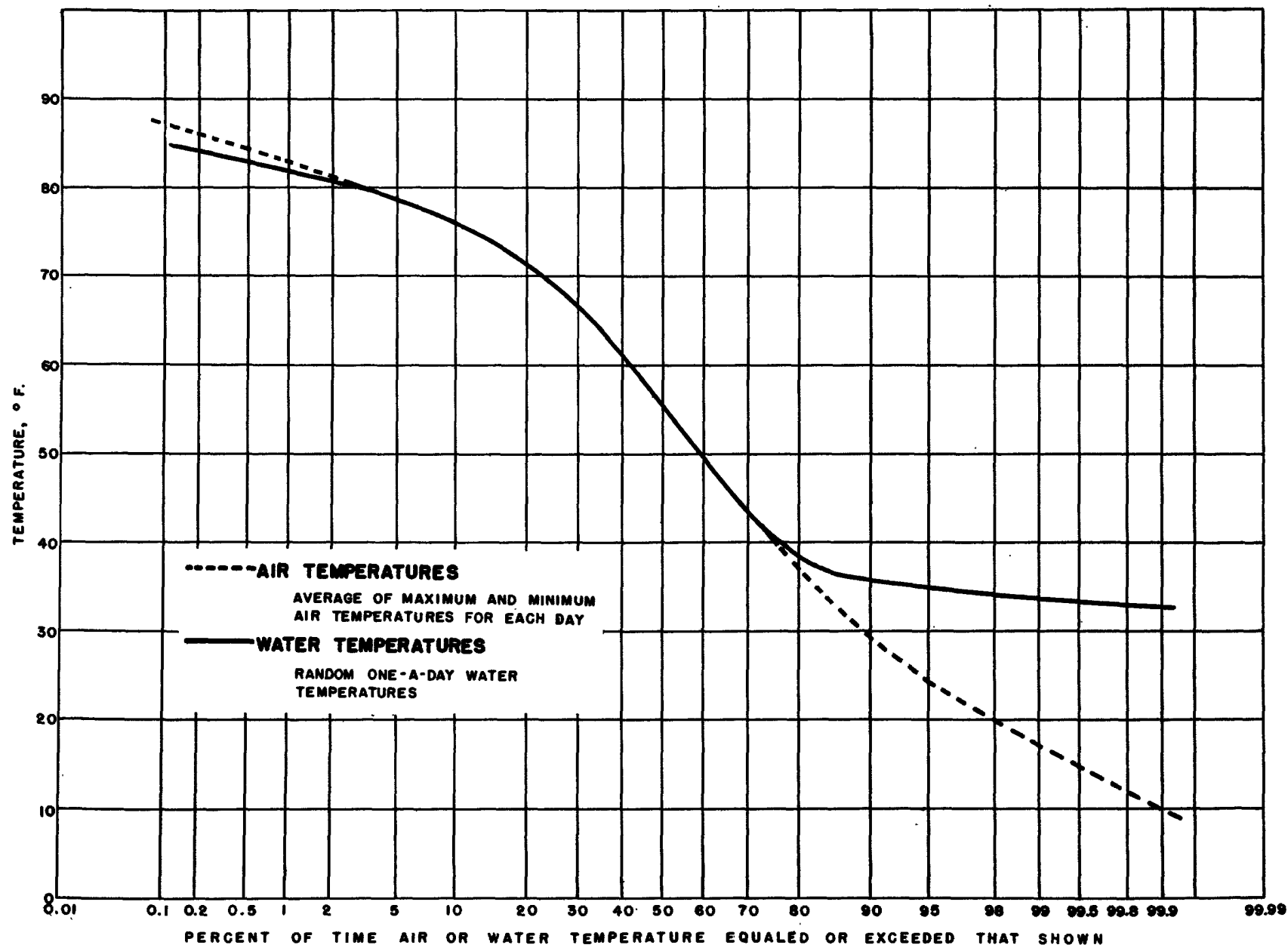

Figure 3.--Air temperature and Delaware River water temperature duration curves, Morrisville, Pa., 
Table 4.--Air and water temperature, Trenton, N. J.

(Degrees Fahrenhe1t)

\begin{tabular}{|c|c|c|c|c|}
\hline \multirow[b]{2}{*}{ Month } & \multicolumn{3}{|c|}{ Delaware River } & \multirow{2}{*}{$\underset{\text { Average }}{\text { Air }}$} \\
\hline & Maximum & Minimum & Average & \\
\hline $\begin{array}{l}\text { January } \\
\text { Febriary } \\
\text { larch } \\
\text { April } \\
\text { Yay } \\
\text { June } \\
\text { JuIy } \\
\text { August } \\
\text { September } \\
\text { October } \\
\text { November } \\
\text { December. }\end{array}$ & $\begin{array}{l}46 \\
45 \\
59 \\
64 \\
72 \\
82 \\
88 \\
84 \\
82 \\
69 \\
66 \\
48\end{array}$ & $\begin{array}{l}34 \\
33 \\
36 \\
45 \\
52 \\
56 \\
68 \\
64 \\
59 \\
49 \\
40 \\
33\end{array}$ & $\begin{array}{l}37 \\
37 \\
44 \\
54 \\
61 \\
70 \\
77 \\
75 \\
71 \\
59 \\
50 \\
38 .\end{array}$ & $\begin{array}{l}32 \\
33 \\
45 \\
52 \\
61 \\
70 \\
76 \\
73 \\
67 \\
57 \\
47 \\
37\end{array}$ \\
\hline
\end{tabular}

Chemical quality of water:-- Chemical analyses of water samples collected dally from the Delaware River at Trenton, N. J. (Morrisville, Pa.). have been made since Oct. 1 , 1944. For each month there were three composite samples, consisting of equal volumes of dails samples for the dates 1-10, 11-20, and 21 to end-of-month. Average analyses for the 5 years of record, and analyses for the periods having maximum and minImum concentrations of dissolved solida are given in table 5 .

Values for dissolved solids in the dally samples ranged from a low of 32 parts per million on Mar. 19, 1945, to a high of 148 parts per million on sept. 15, 1949. The percentage of time in the 5-jear period that the concentration of dissolved solids in dally samples equaled or exceeded any given concentration is shown in flgure 4.

Suspended-sediment discharge.-- Suspended. sediment discharge of the Delaware River at Trenton, N. J., has been determined since Sep. tember 1949. Water discharge in second-foot-days and suspended-sediment dischargo in tons are given in table 6 for the perlod September 1948 through September 1950. The maximum dally suspended-sediment discharge for the perlod was 68,700 tons Mar. 30, 1950; the minimum was 9.2 tons sept. 30,1950 . The maximum dally suspendedsediment concentration was 328 parts per million Dec. 14; 1949; the minimum was 1 part per million on many days.

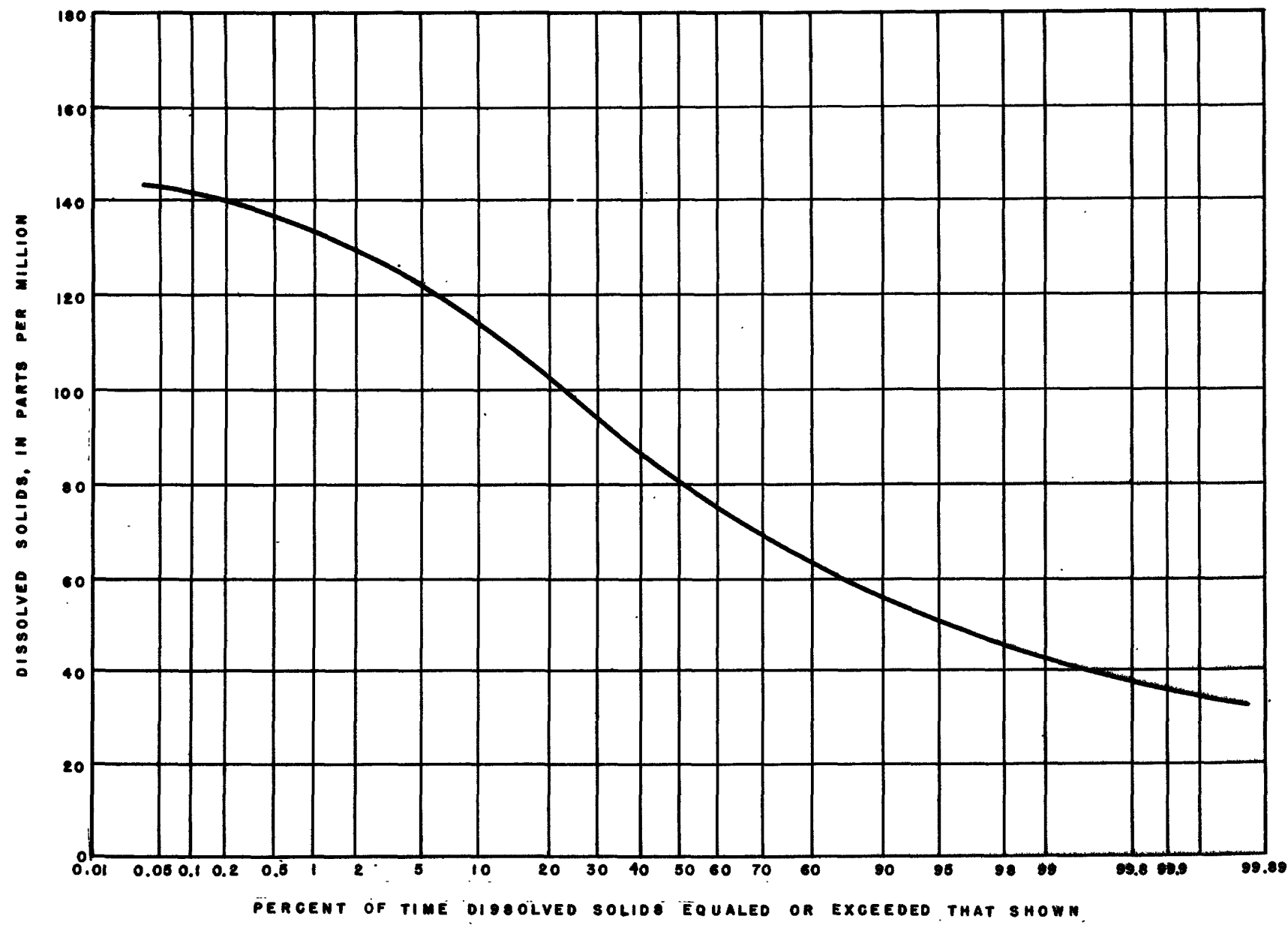

Plgure 4.--Dissoived-solids duration curve, Delaware River at Morrisville, Pa., 1944-49 
Table 5.--Chemical analyses of Delqware River water at Trenton, N. J. (Morrisv11le, Pa.) 1944-49 (Chemical results in parts per million)

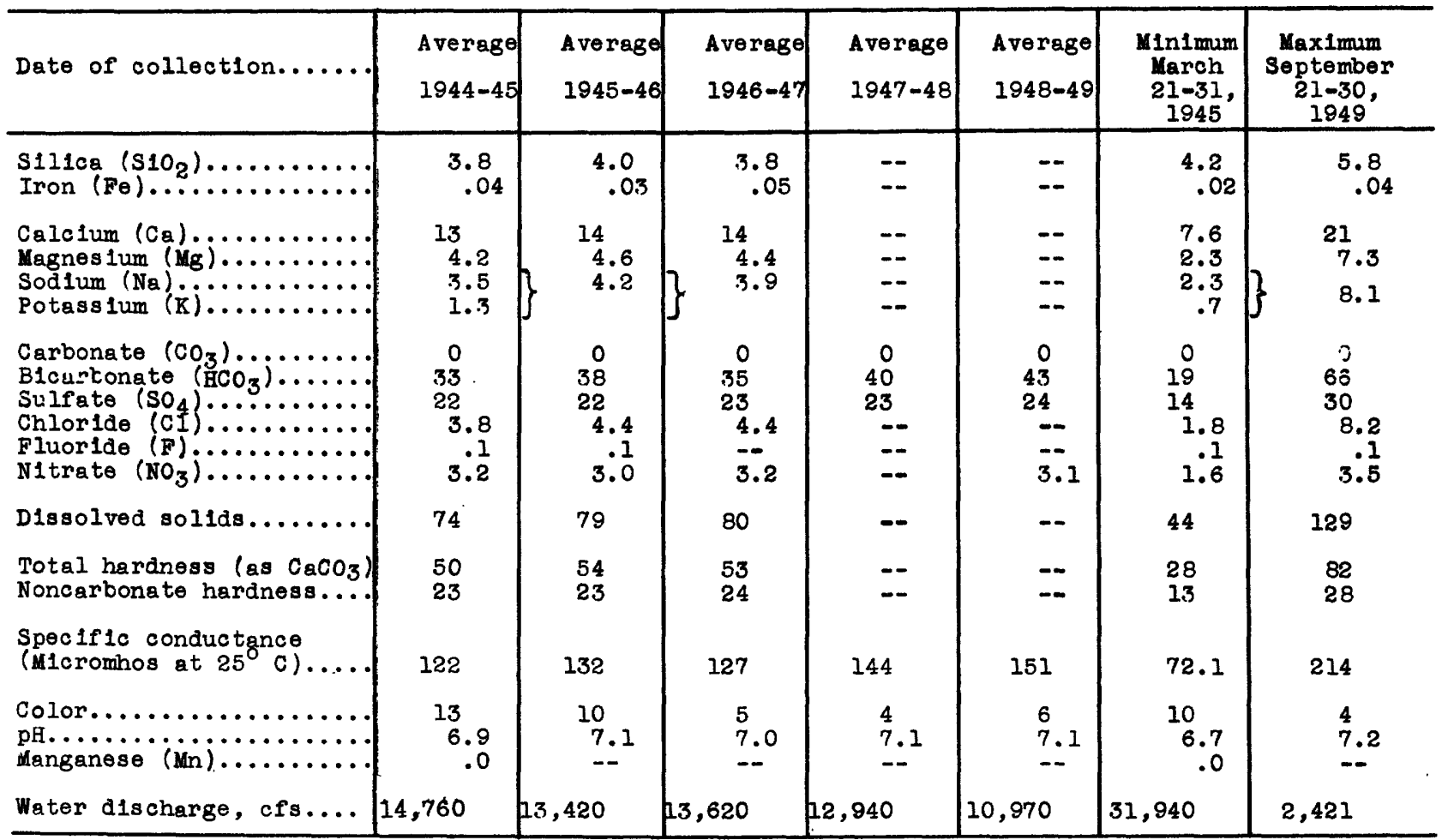

Table 6.--Suspended-sediment discharge, Delaware River at Trenton, N. J., September 1949-September 1950

\begin{tabular}{l|c|c}
\hline Month & $\begin{array}{c}\text { Water } \\
\text { discharge } \\
\text { (second-fot- } \\
\text { days) } 1\end{array}$ & $\begin{array}{c}\text { Sus pended- } \\
\text { sed1ment } \\
\text { discharge } \\
\text { (tons) }\end{array}$ \\
\hline September 1949 & 81,560 & 3,420 \\
October & 86,320 & 1,150 \\
November & 139,800 & 6,350 \\
December & 339,000 & 62,580 \\
January 1950 & 429,900 & 16,760 \\
February & 372,900 & 15,380 \\
March & 677,700 & 200,700 \\
Apr11 & 730,800 & 85,470 \\
May & 420,300 & 10,830 \\
June & 346,500 & 12,460 \\
July & 234,800 & 8,670 \\
August & 152,400 & 6,730 \\
September & 141,600 & 9,300 \\
\hline
\end{tabular}

1 One second-foot-day is the volume of water represented by a flow of 1 second-foot for 24 hours. It is equivalent to 86,400 cublc feet or 646,317 gallons.

\section{Delaware Division of Pennsylvania Canal}

The Delaware Division of the Pennsylvania Canal was constructed by the Commonwealth of Pennsylvania in 1830 as a link in the proposed waterway system connecting Philadelphia and Plttsburgh. After being operated by many private owners during intervening years, it was acquired by the Commonwealth through gift in
1950. The canal, 60 miles in length, orlg1nates in the Lehigh River at Easton and closely follows the Delaware River to Morrisville, $\mathrm{Pa}$. It runs in almost a straight line from Morrisville to its outlet at Bristol.

Since barge traffic was discontinued on it in 1931, plpes have carried the flow of the canal through Morrisville and at many road crossings between Morrisville and Bristol. About 4.5 milIlon gallons a day is diverted from the canal between Morrisvilie and Bristol for Industrial and Irrigational uses. Iittle additional water can be provided for potential water users in the area because of the restricted carrying capacity of the pipes. The Commonwealth has no projects under consideration at the present time to increase the flow in this section of the canal.

\section{Neshaminy Creek}

Neshaminy Creok drains an area of 233 square miles, mostly agricultural and almost entirely within Bucks County. About one-tenth of 1ts drainage basin lies within the area covered by this report. The Philadelphia Suburban Water Service Co. diverts about 3 million gallons a day from Neshaminy Creek at Neshaminy Falls. The Philadelphia Suburban Water Service Co. was granted a permit in $1941 \mathrm{by}$ the Water and Power Resources Board to construct a reservolr with a capac1ty of 650 million gallons on Iron Works Creek at a point half a mile above its mouth. The drainage area above the dam is 6.4 square miles. The permit atipulates that a flow of not less than I cublc foot per second shall be maintalned below the dam except when the natural flow into the reservoir is less than 1 cublo foot per second; then the natural flow into the 
reservolr shall be mainteined below the dam. Water released from the reservolr flows in the natural stream channels to Neshaminy Falls where It is diverted. This current use of Neshaminy Creek must be taken into consideration, when planning future developments. Although NeshamIny Creek is capable of greater utilization, development probably will be slow because of the lack of favorable sites for dams and storage reservolrs.

Gaging and sampling station:--Information has been obtained from time to time during recent jears on the temperature and the chemical quality of Neshaminy Creek water. A continuous record of creek helghts and flow has been kept since October 1934. Inasmich as there were no severe droughts in the perlod 0ctober 1934 to September 1949, an estimate of the low-flow characteristics of the creek has been made on the basis of comparia on with Assunpink Creek at Trenton, N. J., for which records have been collected since 1924, and with the North Branch Rancocas Creek at Pemberton, N. J., for which records have been collected since 1921.

Pertinent data on Veshoming Creek follow:

Location of station: At bridge on State Highway 213, helf a mile downstream from M1ll Creek and 1.7 miles west of Langhorne, $\mathrm{Pa}$. The datum of the gage is 40.57 feet above mean sea level, datum of 1929 , New York-Pennsylvania supplementary adjustment of 1943 .
Drainage area: 210 square miles.
Average discharge: 15 years $(193.4-49), 265$ cfs.
28 jears. $(1921-49), 230$ cfs (estimated.)

Monthly discharge: Average monthly discharges for the perlod 1934-49 are given in table 7 .

Extremes: 1934-49--Maximum discharge, 24,800 cfs, July 23, 1938 (gage helght, 15.94 feet); minimum 5.8 cfs; Nov. 20, 1941; minimum gage helght, 0.58 foot, 0ct. 4, 1937, Aug. 31 and Sept. 1, 1944; minimum daily discharge, 7.1 cfs, Sept. 24, 1939.

Naximum stage lmown, 17.3 feet, Aus. 23, 1933 (discharge, 30,000 cfs.)

Probable flow varlation:-The probable flow variation of Neshaminy Creek, is shown by the flow-duration curve, figure 5 , and the curve showing the discharge avallable without storage, figure 6. The flow-duration curve shows the percent of time that a specifled dally discharge in cublc feet per second per square mile has been equaled or exceeded. It may be treated as a probablilty curve and used to estimate the probability of occurrence of a specifled discharge. Figure 6 shows the longes.t perlod of time that the discharge was less than a specifled amount.

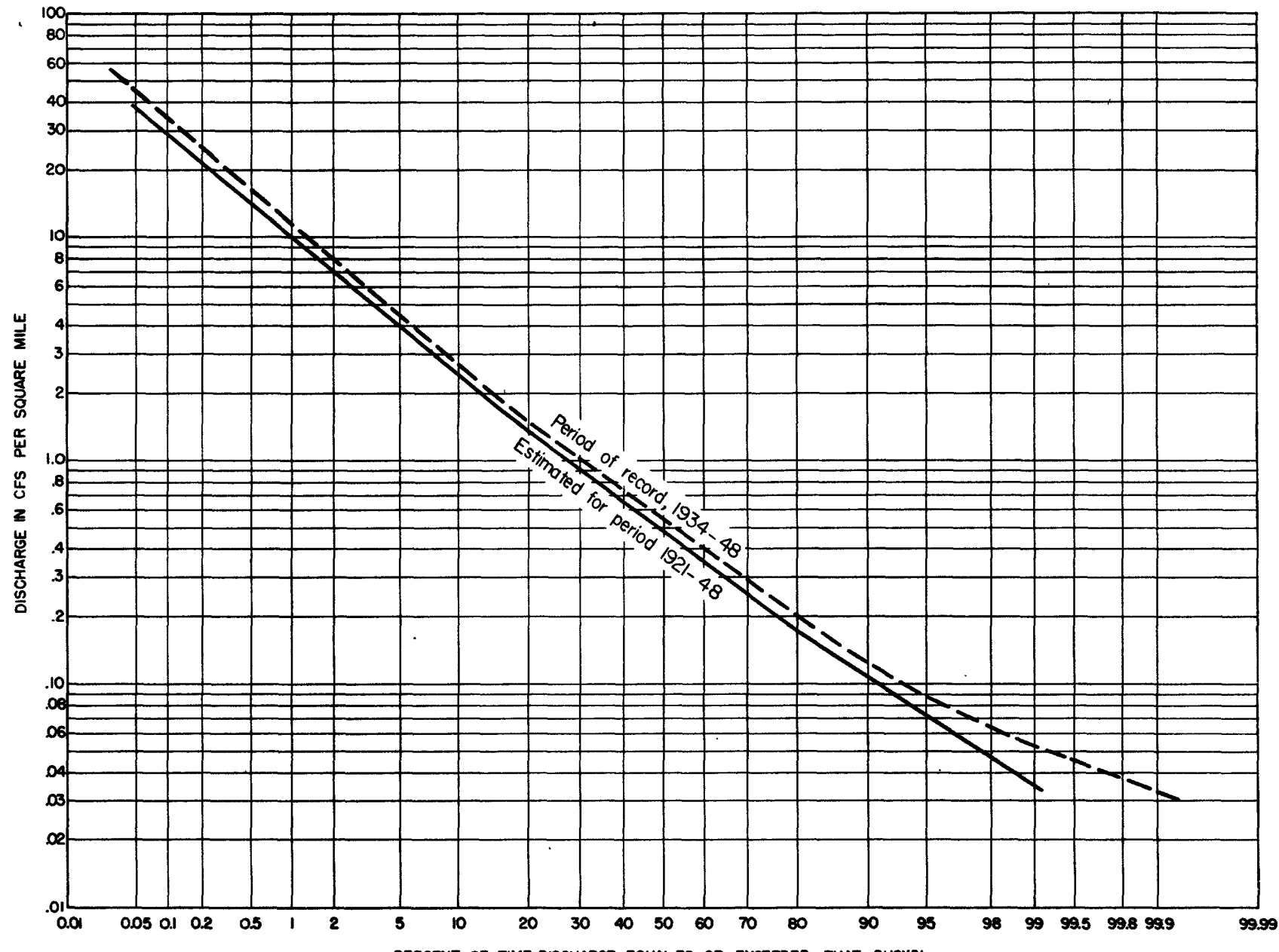

PERCENT OF TIME DISCHARGE EQUALED OR EXCEEDED THAT SHOWN

Figure 5.--Flow-duration curve for Neshaminy Creek near Langhorne, Pa. 
Table 7--Average monthly and annual discharge of Neshaminy Creek near Langhorne, Pa. (Cubic feet per second)

\begin{tabular}{c|c|c|c|c|c|c|c|c|c|c|c|c|c}
\hline Year & oct. & Nov. & Dec. & Jan. & Feb. & Mar. & Apr. & May & June & July & Aug. & Sept. & Annual \\
\hline $1934-35$ & 228 & 135 & 271 & 306 & 548 & 394 & 177 & 83.1 & 58.2 & 117 & 105 & 223 & 218 \\
$1935-36$ & 85.6 & 411 & 214 & 771 & 349 & 1,163 & 410 & 138 & 58.6 & 41.5 & 59.6 & 23.8 & 311 \\
$1936-37$ & 36.1 & 23.2 & 362 & 750 & 402 & 309 & 334 & 221 & 74.5 & 64.7 & 39.8 & 20.2 & 219 \\
$1937-38$ & 80.6 & 481 & 152 & 308 & 380 & 339 & 149 & 85.2 & 289 & 1,161 & 174 & 633 & 352 \\
$1938-39$ & 126 & 103 & 625 & 349 & 1,074 & 610 & 713 & 140 & 75.2 & 33.0 & 65.8 & 16.1 & 323 \\
$1939-40$ & 28.0 & 80.4 & 47.7 & 101 & 352 & 858 & 882 & 264 & 139 & 50.4 & 43.6 & 92.6 & 244 \\
$1940-41$ & 48.0 & 379 & 342 & 316 & 296 & 479 & 319 & 55.9 & 62.5 & 330 & 95.8 & 28.1 & 229 \\
$1941-42$ & 16.4 & 29.2 & 120 & 157 & 325 & 562 & 255 & 74.1 & 49.1 & 78.4 & 313 & 57.3 & 169 \\
$1942-43$ & 82.2 & 214 & 559 & 236 & 571 & 391 & 197 & 336 & 213 & 87.1 & 30.8 & 16.0 & 243 \\
$1943-44$ & 119 & 264 & 107 & 496 & 201 & 668 & 608 & 192 & 124 & 32.0 & 15.8 & 65.5 & 241 \\
$1944-45$ & 25.3 & 208 & 261 & 333 & 642 & 38.3 & 226 & 293 & 157 & 629 & 232 & 348 & 309 \\
$1945-46$ & 111 & 393 & 575 & 336 & 208 & 422 & 151 & 287 & 712 & 443 & 106 & 58.5 & 318 \\
$1946-47$ & 44.2 & 36.7 & 69.0 & 241 & 115 & 343 & 278 & 594 & 220 & 75.6 & 71.6 & 67.1 & 180 \\
$1947-48$ & 41.3 & 444 & 173 & 283 & 645 & 596 & 421 & 849 & 374 & 149 & 150 & 60.1 & 347 \\
$1948-49$ & 34.1 & 79.0 & 578 & 848 & 593 & 369 & 286 & 240 & 69.7 & 127 & 39.2 & 82.3 & 278 \\
& & & & & & & \\
Max1mum & 228 & 481 & 625 & 848 & 1,074 & 1,163 & 882 & 849 & 712 & 1,161 & 313 & 6.33 & 352 \\
M1n1mum & 16.4 & 23.2 & 47.7 & 101 & 115 & 309 & 149 & 55.9 & 49.1 & 32.0 & 15.8 & 16.1 & 169 \\
Mean & 73.7 & 219 & 297 & 389 & 447 & 526 & 360 & 257 & 178 & 228 & 103 & 119 & 265 \\
\hline
\end{tabular}

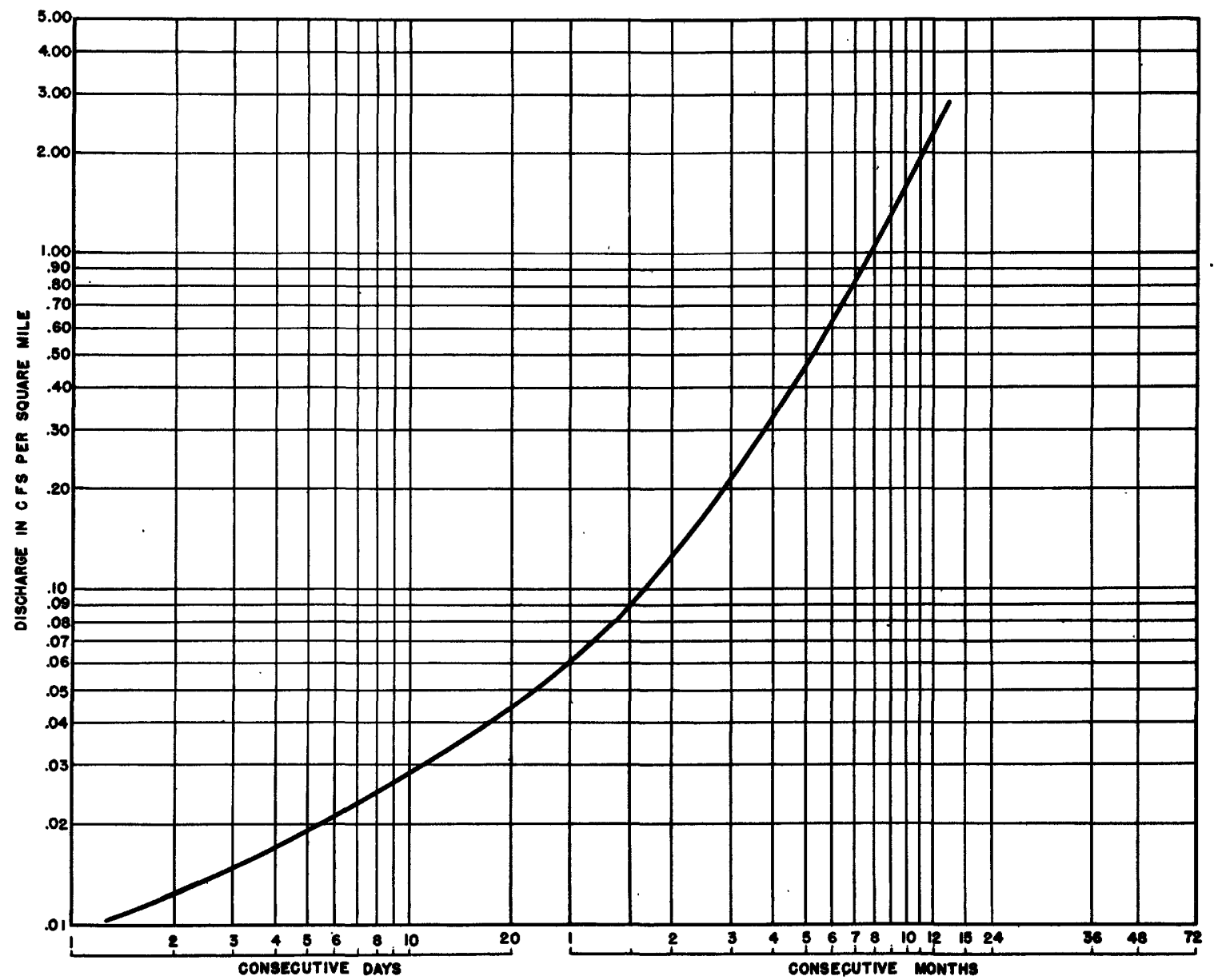

Figure 6.--Discharge available without storage in Neshaminy Creek near Langhorne, Pa. 
In addition to giving graphically the general flow characteristics of the stream, these curves are valuable for use in solving problems of plant location and operation. For example, assume that it is desired to locate a manufacturing plant on Neshaminy Creek at a point where the drainage area happens to be 200 square miles. Construction of a storage dam is not contemplated. A flow of 10 cubic feet per second, or 0.05 cublc foot per second per square mile, is required to operate the plant. It is necessary to know the average number of days each year that there w11l be a shortage of water. Using the curve based on the estimated $1921-48$ record (solid line, fig. 5) it is seen that a flow equal to or exceeding 0.05 foot per second per square mile will prevali during 98 percent of the time. The estimated curve for the period 1921-48 is used because that period included extreme droughts and floods and is considered to be more nearly representative of average conditions then the period of actual record, 193448. For an average year, there would be sufficlent water. 98 percent of 365 or 358 days, and a shortage for only 7 days. IIt may be possible to operate the plant for short periods on less than 10 cubic feet per second. However, it is nocessary to kmow the maximum number of consecutive days, even in unusual yoars, that the flow will be less than 10 cublc feot per second. Figure 6, based on the estimated record for the perlod 1921-48, shows that the flow of Neshaminy Creek may be expected to be less than 0.05 cubic foot per second per square mile for not more than 24 consecutive days.
Water temperature:-No dally measurements of temperature have been made. However, miscellaneous measurements made from 1944 to 1950 indicate that the stream is at 1ts warmest during July, when a high of about $80^{\circ} \mathrm{F}$. may be expected. Slightly lower temperatures can be expected during Augus t. Temperatures ranging from $32^{\circ}$ to $80^{\circ} \mathrm{F}$. have been measured at the Ianghorne station.

Chemical quality of water:-Thirty-five analyoes of samples collected from Neshaming Creek at Ianghorne are avallable for the perlod from 1944 to 1950. Samples having the lowest and highest concentrations of dissolved solids, as indicated by specific. conductance, together with an analy$s$ is considered typical of the water in the stream much of the time, are given in table 8 .

\section{other stresms}

There are three other streams of significance in the area. The y are K111, Common, and Poquessing Creoks. Their draining areas are 19.2, 11.9, and 21 square miles, respectively. Gaging sta. tions here have not been maintained on these s treams.

The nost serlous drought of record in Bucks County was that of 1930 , when a total of only 30.81 inches of precipitation was recorded at George School. No discharge measurements were made of any of the foregoing streams during that critical perlod. However, the flow of 1112 Creek and Common Creek was measured several

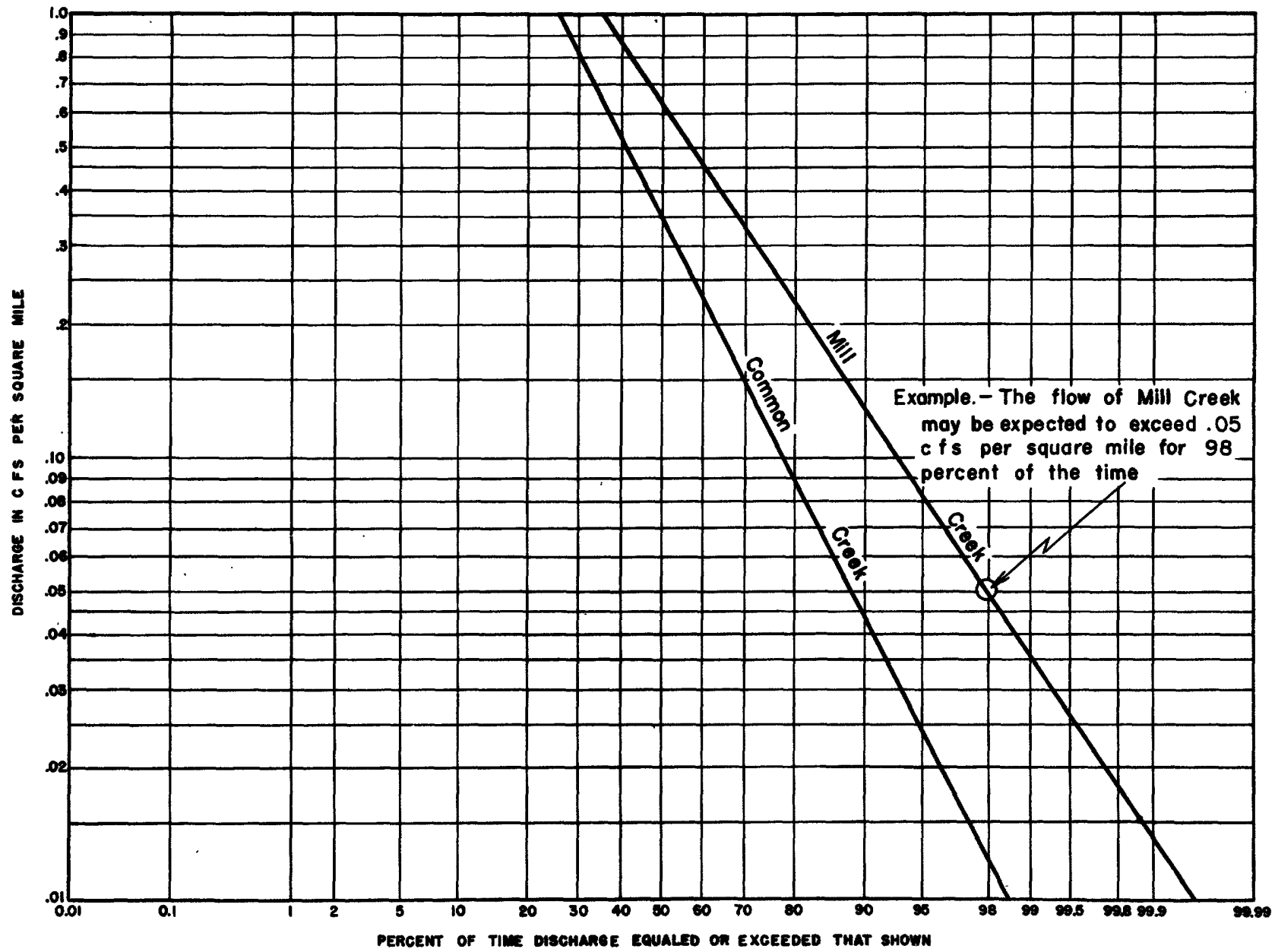

P1gure 7.--Flow-duration curves for Mill Creok and Common Creek 
Table 8.--Chemical quality of Neshaminy Creek water near Lenghorne, $\mathrm{Pa}$.

(Chemical results in parts per million)

\begin{tabular}{|c|c|c|c|}
\hline $\begin{array}{l}\text { Date of } \\
\text { collection........ }\end{array}$ & $\begin{array}{c}\text { Lowest } \\
\text { Feb. } 19 \\
1948\end{array}$ & $\begin{array}{c}\text { Highest } \\
\text { Dec. } 14, \\
1949\end{array}$ & $\begin{array}{l}\text { Typical } \\
\text { May } 19, \\
1950\end{array}$ \\
\hline 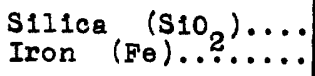 & -- & $m$ & $\begin{array}{l}8.4 \\
.22\end{array}$ \\
\hline $\begin{array}{l}\text { Calcium }\left(\mathrm{Ca}_{a}\right) \ldots \ldots \\
\text { Magnesium }(\mathrm{Mg}) \ldots \ldots \\
\text { Sodium (Na) } \ldots \\
\text { Potassium }(\mathrm{K}) \ldots \ldots\end{array}$ & $\begin{array}{l}9.6 \\
4.6 \\
2.8\end{array}$ & --- & $\begin{array}{l}14 \\
5.8 \\
10\end{array}$ \\
\hline 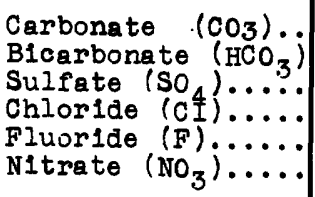 & $\begin{array}{c}0 \\
16 \\
23 \\
4 \\
---\end{array}$ & $\begin{array}{l}0 \\
70 \\
34 \\
17 \\
-8.8\end{array}$ & $\begin{array}{r}0 \\
42 \\
31 \\
7.1 \\
.2 \\
5.4\end{array}$ \\
\hline $\begin{array}{l}\text { Dissolved solids.. } \\
\text { Total hardness } \\
\text { (as } \mathrm{CaCO}_{3} \text { )........ } \\
\text { Noncarbonate hard- } \\
\text { ness............. }\end{array}$ & 43 & 82 & $\begin{array}{r}116 \\
59 \\
24\end{array}$ \\
\hline $\begin{array}{l}\text { Specific conduct- } \\
\text { ance (Micromhos } \\
\left.\text { at } 25^{\circ} \text { C }\right) \ldots \ldots \ldots\end{array}$ & 107 & 267 & 174 \\
\hline 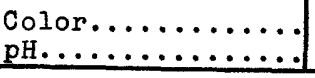 & $\begin{array}{c}30 \\
6.1 \\
\end{array}$ & $\begin{array}{l}28 \\
7.7 \\
\end{array}$ & $\begin{array}{r}26 \\
6.9 \\
\end{array}$ \\
\hline
\end{tabular}

times during 1950. These discharge messurements have been correlated with continuous discharge records for Neshaminy Creek near Langhorne, Pa., Assunpink Creek at Trenton, N. J., and the North Branch of Rancocas Creek at Pemberton, N. J., in order to estimate the low-flow and other hydrologic characteristics of Mill and Common Creeks.

The average discharge is measure of the total flow and is therefore equal to the ult1mate supply that can be developed from the stream. The estimated average discharges for M111 Creek and Common Creek are 0.9 and 0.6 cublc foot.per second per square mile, respectively. The low discharge portions of the flowduration curvos for these streams are shown in flgure 7. The maximum number of consecutive days that the discharge may be expected to be less than given amount is shown In figure $8 .$. An example of the use of these figures is given with the data for Neshaminy Creek (p.ll).

Chemical analyses, of water from small streams in the area are given in table 9 . Although the anelyses doubtless do not represent extremes of concentrations tinat may be obtained, they probably are typical of the quality of the water avaliable in the streams much of the time.

PLANS FOR THE REGULATION OF THE SURFACE WATERS OF THE DELAWARE RIVER BASIN

The Delaware River Basin and the adjoining territory to which it is economicaliy related have aptiy been referred to as the heart of the northeastern section of the United States. About 5 mililon people reside within the Basin. An

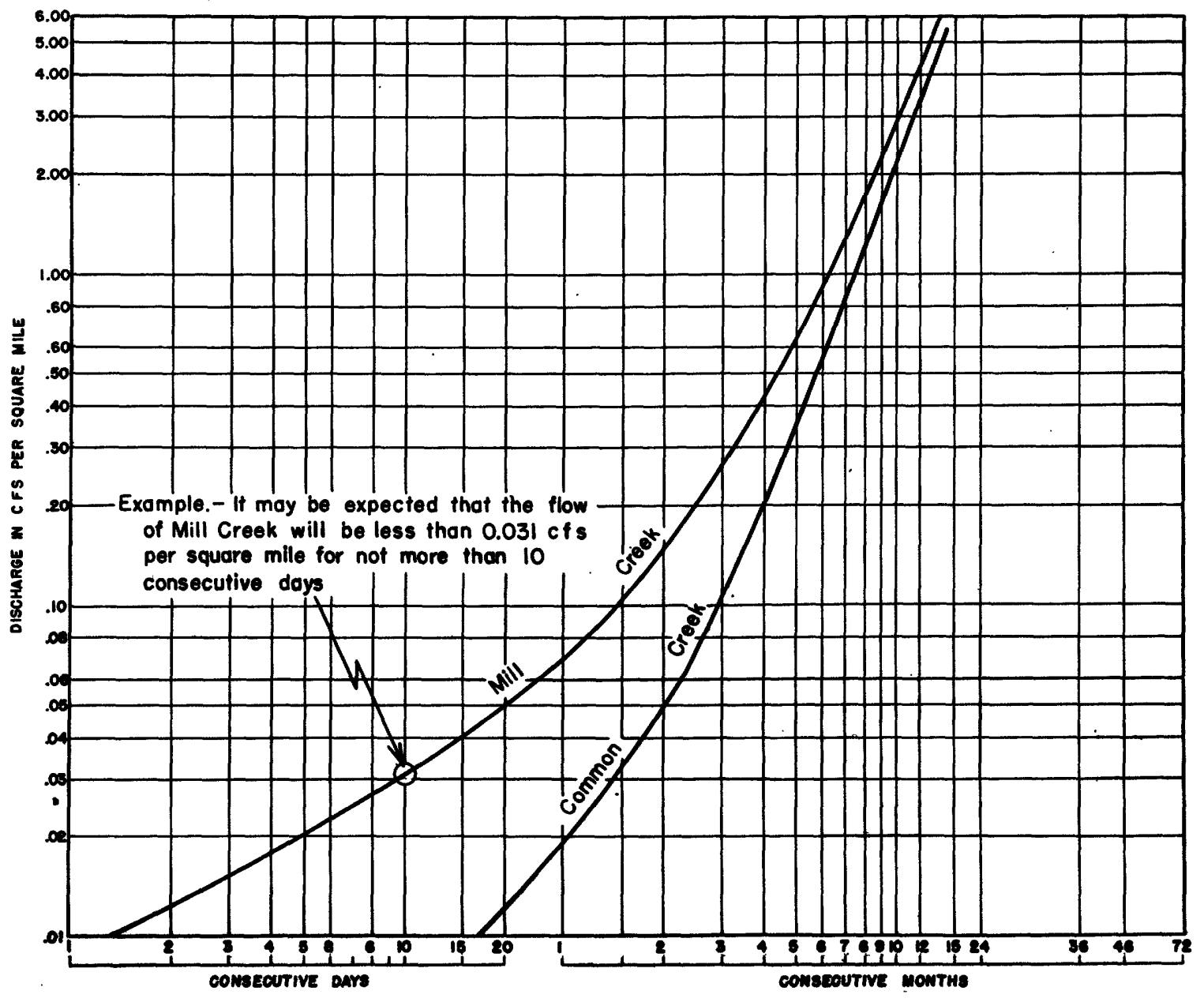


Table 9--Chemical quality of the waters of small streams in southeastern Bucks County, Pa.

(Chomical results in parts per mililon)

\begin{tabular}{|c|c|c|c|c|c|c|c|c|}
\hline Location & 1 & 2 & 3 & 4 & 5 & 6 & 7 & 8 \\
\hline Date of collection & $\underset{1950}{J u n e} 7$, & $\begin{array}{c}\text { May 4, } \\
1950^{\circ}\end{array}$ & $\operatorname{Jun}_{1950} 7$, & $\operatorname{Jun}_{1950} 23$, & ${ }_{1950}^{\text {Aug. }}$ & $\begin{array}{c}\text { Aug. } 16, \\
1950\end{array}$ & ${ }_{1950}{ }^{16}$ & $\begin{array}{c}\text { July } 28, \\
1950\end{array}$ \\
\hline $\begin{array}{l}\text { Silica }\left(\mathrm{s}_{10}\right) \ldots \ldots \ldots \ldots \ldots \\
\text { Iron }(\mathrm{Fe}) \ldots \ldots \ldots \ldots \ldots \ldots\end{array}$ & $\begin{array}{l}8.6 \\
.69\end{array}$ & --- & $\begin{array}{c}6.7 \\
.81\end{array}$ & $\begin{array}{l}7.6 \\
.14\end{array}$ & $\begin{array}{l}7.6 \\
.16\end{array}$ & $\begin{array}{l}3.8 \\
.28\end{array}$ & $\begin{array}{c}3.4 \\
.17\end{array}$ & 12.20 \\
\hline 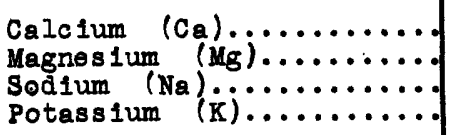 & $\begin{array}{l}8.7 \\
4.2 \\
3.2 \\
1.5\end{array}$ & $m-\overline{-}$ & $\begin{array}{l}9.4 \\
5.0 \\
5.8 \\
2.1\end{array}$ & $\begin{array}{r}13 \\
7.6 \\
8.0 \\
3.0\end{array}$ & $\begin{array}{r}17 \\
9.3 \\
4.7 \\
3.0\end{array}$ & $\begin{array}{r}17 \\
8.7 \\
6.0 \\
2.6\end{array}$ & $\begin{array}{r}17 \\
8.7 \\
6.1 \\
1.4\end{array}$ & $\begin{array}{l}12 \\
4.6 \\
11 \\
2.3\end{array}$ \\
\hline 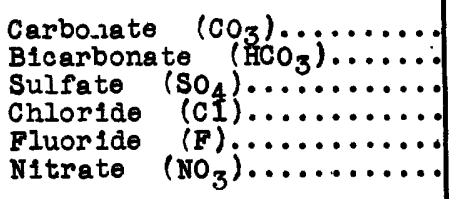 & $\begin{array}{r}0 \\
16 \\
20 \\
7.0 \\
.2 \\
5.4\end{array}$ & $\begin{array}{r}0 \\
13 \\
28 \\
7 \\
-2 \\
3.0\end{array}$ & $\begin{array}{l}0 \\
11 \\
36 \\
7.2 \\
3.2\end{array}$ & $\begin{array}{r}0 \\
3 \\
61 \\
9.0 \\
.2 \\
5.8\end{array}$ & $\begin{array}{r}0 \\
0 \\
143 \\
16 \\
.1 \\
.9\end{array}$ & $\begin{array}{l}0 \\
50 \\
40 \\
11 \\
.1 \\
.1\end{array}$ & $\begin{array}{l}0 \\
33 \\
50 \\
12 \\
.1 \\
.12\end{array}$ & $\begin{array}{l}0 \\
28 \\
20 \\
16 \\
13\end{array}$ \\
\hline Dissolved solids....... & 90 & -- & 99 & 126 & 228 & 132 & 129 & 128 \\
\hline $\begin{array}{l}\left.\text { Total hardness (as } \mathrm{CaCO}_{3}\right) \\
\text { Noncarbonate hardness }\end{array}$ & $\begin{array}{l}39 \\
26\end{array}$ & $\begin{array}{l}36 \\
25\end{array}$ & $\begin{array}{l}44 \\
35\end{array}$ & $\begin{array}{l}64 \\
61\end{array}$ & $\begin{array}{l}159 \\
159\end{array}$ & $\begin{array}{l}78 \\
37\end{array}$ & $\begin{array}{l}78 \\
51\end{array}$ & $\begin{array}{l}49 \\
26\end{array}$ \\
\hline $\begin{array}{l}\text { Specific conductance } \\
\text { (Micromhos at } 25^{\circ} \text { c.).... }\end{array}$ & 119 & 112 & 136 & 204 & 354 & 195 & 203 & 180 \\
\hline 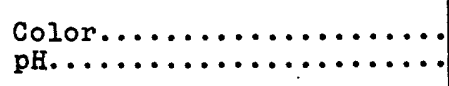 & $\begin{array}{l}18 \\
6.7\end{array}$ & $\begin{array}{l}26 \\
6.7\end{array}$ & $\frac{13}{6.5}$ & $\begin{array}{l}4 \\
4.6\end{array}$ & $\begin{array}{l}8 \\
3.75\end{array}$ & $\begin{array}{l}8 \\
6.9\end{array}$ & $\begin{array}{l}7 \\
6.5\end{array}$ & 6.9 \\
\hline Water discharge, cfs.. & 13 & --- & 6.6 & 2.3 & --- & -- & -- & 12 \\
\hline
\end{tabular}

1. M111 Creek at Magnolia Avenue, Bristal, Pa.

2. Queon Anno Creok near Bristol, $\mathrm{Pa}$.

3. Common Creok at Tullytown, $\mathbf{P a}$.

4. Common Creek at Tullytown, $\mathrm{Pa}$.

5. Rock Run at Tyburn Road, Fallsington, $\mathrm{Pa}_{\mathrm{a}}$

6. Scotts Creok-Penn Manor Lake near Tuliytown, Pa.

7. Van Sciver Lake at Bordentown Road near Tullytown, $\mathbf{P a}$.

8. Poquessing Crook at Philadelphia, Pa.

additional 10 million people, largely in the metropolitan areas of New York City and northeastern New Jersey, are dependent in part upon the development and ut1lization of its water resources.

Anticipating future needs, the States of New York, New Jersey, and Penns ylvania have individually carried on many studies in the past to devejop a plan to utilize the head waters of the basin. It was not unt1l 1949 that these States took definite steps toward an integrated plan for meeting the prospective water-supply requirements of their political divisions and metropolitan areas. During the 1949 legislative sesslons, the States of New York, New Jersey, and Pennsylvania passed reciprocal acts directing the Interstate Commission on the Delaware River Basin (Incodel) to be responsible for surveys and investigations to gain this objective.

A full report setting forth its conclusions and recommendations is to be made by Incodel to the Governors and Legislatures of the three States by January 15,1951 . A prellminary report by Incodel states that the first stage of the development should be construction in the upper bas in of torage reservolrs of sufficlent capacity to satisfy the additional water requirements of northern New Jersey and the New York City metropolitan area for the next 25 years and to maintain a minimum flow of 4,000 cubic feet per second in the Delaware River at Trenton.

\section{GROUND WATER}

Ground water occurs in abundance in southeastern Bucks County. Wherever it flows from springs or is pumped from wells it is characteristically clear. Its nearly constant temperature is about the same as the a verage annual air temperature. It is clear because sediment and other suspended matter settle or filter out as the water slowiy moves from the point where it enters the ground toward some lower outlet. The water has a very small temperature range because the earth does not vary much in temperature throughout the year at depths more than a few feet below the land. surface.

These properties make ground water desirable, particularly for indistrial cooling processes where constant temperatures are necessary. At present, industries and municipalitios in the area use about 12 million gallons of water a day during summer and perhaps 7 to 8 million gallons a day during winter, when the demand is least. Most of this water is obtained from relatively shallow wells in sand and gravel near the Delaware River. Many of these wells are capable of jielding several hundred gallons a minute. Only a small part of the ground water used is obtained from springs. 
Geology of the Area

The geologic and geographical characteristics of an area, together with its climate, control the occurrence of ground water. The kinds of formations under the land surface and their shape and attitude in relation to one another and to the land surface determine the amount of water held in the ground and its movement from areas of recharge to discharge.

The oldest geologic formations in southeastern Bucks County belong to the pre-Cambrian era generally considered to have ended 500 million years ago. These are consolidated rock formations somewhat similar in physical properties to granite, and are called schist, gneiss, and quartzite. In the Pledmont region of low hilis outside the Delaware River Valloy these formations lie just beneath the soll cover. At the fall line (see pl. I) where the low hilis (those bem tween 40 and 200 feet above mean sea level) meet the flat valley plain of the Delaware, the rock surface dips beneath a series of clay, sand, and gravel layers. The oldest of the se layers of sediment were deposited perhaps 100 to $150 \mathrm{mll}$ lion years ago. The younger sediments were laid down considerably later, within the past mililon years and during the glaclal period. Beneath these layers of clay, sand, and gravel the preCambrian rock. surface dips southeast 40 to 60 feet to the mile. At the widest part of the Valley in southern Bucks County the rock surface is generally 100 to 200 feet below the land surface. Land-surface elevations in the Valley are mostly between 10 and 40 feet above mean sea level.

\section{Relation of Geology to. Ground-Water Supply}

There is a great difference geologically between the hard rocks northwest of the fall line, and the clay, sand, and gravel sediments of the Coestal Plain and lower Delaware River Valley, and there is just as great a difference in the ground-water resources of the two areas. The hard rocks forming the low hills northwest of the fall line and the bedrock surface beneath the Delaware River Valloy are not very permeablo. Water is present and moves largely in crevices or fractures, produced by earth movements and, in some rocles enlarged by weathering and solut1on. These openings normally make up only a small percentage of the total mass of the rock. Consequently, the quantity of water that can be stored in such rock is small. No valid methods have yet been devised for predicting, from the surface, the precise location of these secondary openings in rocks and for determining their water-bearing properties in advance of driling. Experience has shown, however, that more waterbearing openings are likely to be present in these rosks beneath valleys than beneath hills. Driling is necessary in each case before the yield of a well in such rocks can be determined.

Conversely, the unconsolidated materlals, such as the sands and gravels, partly filling the valley of the Delaware River and forming the oxtensive Coastal Plain, contain innumerable small openings or pores between the grains makIng up the sediments. Such openings generaliy provide a much more dependabie and larger yield than is çommon for the hard-pock formations. It is frequently possible to make relatively accurate estimates of the depth to these waterbearing layers, Jield, and even temperature and quality of the water at a given site before a well is arilied. Such estimates are based on careful study of records for other wells in the area and on knowledge of the local geology.
Figure 9 is a map of southeastern Bucks County showing areas of low and high yleld of wells and areas of present heavy pumping from wells.

A comparison of the average depth and yield of municipal and industrial weils for the pledmont area and the area of sand and gravel follows:

\begin{tabular}{l|c|r|r|r}
\hline $\begin{array}{l}\text { Water-bearing } \\
\text { formations }\end{array}$ & $\begin{array}{c}\text { No. } \\
\text { of } \\
\text { wells }\end{array}$ & $\begin{array}{r}\text { Average } \\
\text { depth } \\
\text { (feet) }\end{array}$ & $\begin{array}{c}\text { Yverage } \\
\text { (gpm) }\end{array}$ & $\begin{array}{c}\text { Maximum } \\
\text { (gpm) }\end{array}$ \\
\hline $\begin{array}{l}\text { Consolidated } \\
\text { rocks (seh1st, } \\
\text { gne1ss, quart- } \\
\text { zite) }\end{array}$ & 31 & 241 & 54 & 275 \\
$\begin{array}{l}\text { Sands and } \\
\text { grayels }\end{array}$ & 41 & 61 & 320 & 1,050 \\
\hline
\end{tabular}

\section{Chomical Quality of Ground Fater}

The small amount of information avallable indicates that the chemical quality of ground waters within the area varies from place to place. No information is available concerning the variation in chemical quality of any one ground-water source over a perlod of jears. In general, the ground waters have about the same chemloal quality as that of streams during perlods when the stream flow is unaffected by surface runoff from precipitation. In Falls Township it has been noted that the water from shallow wells is higher than normal in concentration of dissolved solids. This is believed to be the result of repeated application of fertilizer to the land in the area and of poor drainage. The chemical quality of water in shallow weils close to the Delaware River is similar to the quality of river water. The temperature of the ground water where it is unaffected by river infiltration remains faifly constant throughout the year, in the range of $53^{\circ}$ to $58^{\circ} \mathrm{F}$. It is believed that the water is satisfactory for most uses. However, in a fow localities the iron content may be too high to permit use of the water without treatment.

Analyses of water from 24 wells in southeastern Bucks County in the area southeast of the fall line were made in 1950. Those showing the highest and lowest concentrations of dissolved solids, together with five other analyses considered representative of ground-water quality, are given in table 10. All wells sampled yleld water from sand-and-gravel aquifers at depths ranging from 20 to 70 feet below the land surface.

\section{Ground-Water Potentialities in the Valley Deposits}

Ground-water supplies in sufficient quantity to supply municlpalities and to attract industry are confined largely to the sand-and-gravel area southeast of the f.all line. Although large quantities of water are being withdrawn from these deposits at a few locelities, such is the Bristol municipal well field and at the Rohm and Haas Chemical Co. plant at Bristol, much greater supplies are believed to be avallable, if properiy developed. It is probable that several times the quantity of ground water now beling used could be pumped from undeveloped areas in the valley deposits, even Ignoring induced infiltration from the river. The broad valley plain is underlain in large part by sand and gravel or sandy soll, which permit rapid infiltration of precipitation to the underground 


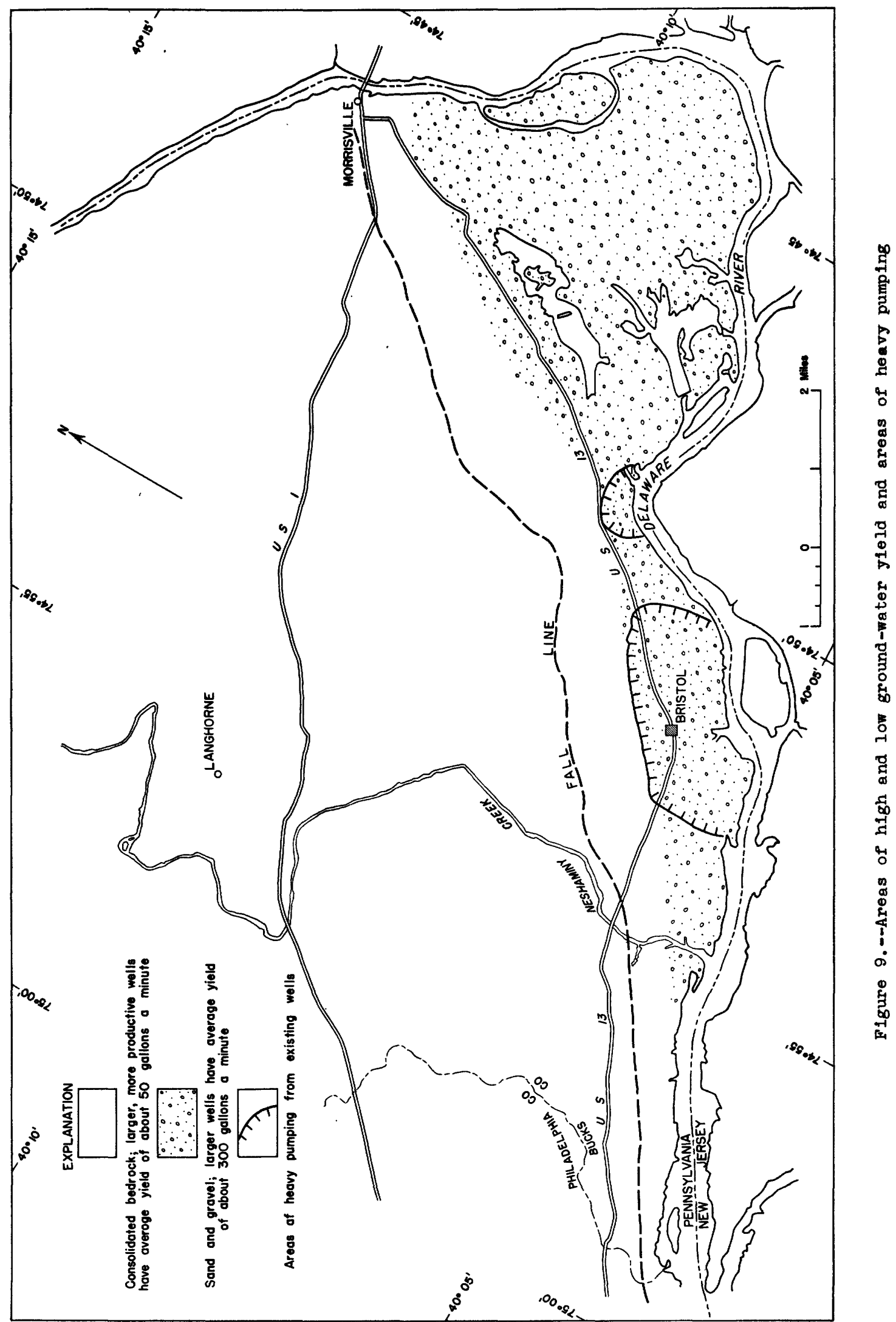


Table 10.--Chemical quality of ground water in southeastern Bucks County, Pa.

(Chemical results in parts per million)

\begin{tabular}{|c|c|c|c|c|c|c|}
\hline Location & 1 & 2 & 3 & 4 & 5 & 6 \\
\hline Date of colloction, $1950 \ldots$ & Aug. 16 & May 25 & June 13 & June 13 & May 25 & June 13 \\
\hline $\begin{array}{l}\text { Silica }\left(\mathrm{SIO}_{2}\right) \ldots \ldots \ldots \ldots \\
\text { Iron, in solution }(\mathrm{Fe}) \ldots \ldots \ldots \\
\text { Iron, total (Fo) } \ldots \ldots \ldots \ldots \ldots\end{array}$ & 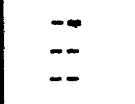 & ${ }_{-}^{12} .03$ & $\begin{array}{l}14.11 \\
2.0\end{array}$ & $\begin{array}{l}6.9 \\
.04 \\
1.6\end{array}$ & $\begin{array}{r}7.4 \\
-.06\end{array}$ & $\begin{array}{r}9.9 \\
.10 \\
.43\end{array}$ \\
\hline 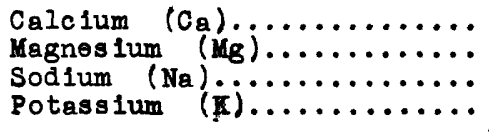 & $\begin{array}{l}-- \\
-- \\
--\end{array}$ & $\begin{array}{r}9.4 \\
4.4 \\
4.8 \\
.9\end{array}$ & $\begin{array}{r}8.2 \\
7.6 \\
11 \\
1.8\end{array}$ & $\begin{array}{r}22 \\
8.5 \\
5.6 \\
2.5\end{array}$ & $\begin{array}{l}47 \\
25 \\
5.9 \\
3.4\end{array}$ & $\begin{array}{l}57 \\
43 \\
76 \\
12\end{array}$ \\
\hline 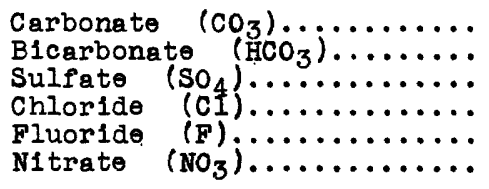 & $\begin{array}{l}0 \\
8 \\
3.3 \\
5.0 \\
-6.6\end{array}$ & $\begin{array}{r}0 \\
24 \\
20 \\
5.2 \\
.1 \\
5.8\end{array}$ & $\begin{array}{r}0 \\
8 \\
45 \\
17 \\
1.1\end{array}$ & $\begin{array}{r}0 \\
62 \\
37 \\
9.9 \\
.0 \\
3.4\end{array}$ & $\begin{array}{r}0 \\
60 \\
113 \\
24 \\
42^{.1}\end{array}$ & $\begin{array}{r}0 \\
53 \\
189 \\
122 \\
0 \\
107\end{array}$ \\
\hline 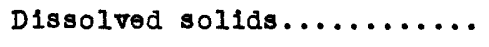 & -- & 77 & 115 & 1.34 & 3.34 & 716 \\
\hline $\begin{array}{l}\text { Specific conductance } \\
\text { (micromhos at } 25^{\circ} \text { c.)...... }\end{array}$ & 72.5 & 118 & 183 & 225 & 503 & 1,090 \\
\hline 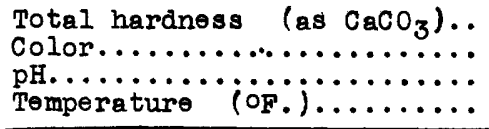 & $\begin{array}{r}16 \\
56 \\
56\end{array}$ & $\begin{array}{l}42 \\
6 \\
6 \cdot \cdot 5\end{array}$ & $\begin{array}{l}52 \\
3 \\
5.2 \\
53\end{array}$ & $\begin{array}{c}90 \\
2 \\
6.5 \\
58\end{array}$ & $\begin{array}{c}220 \\
3 \\
6.4 \\
56\end{array}$ & $\begin{array}{c}319 \\
3 \\
6.3 \\
53\end{array}$ \\
\hline
\end{tabular}

1. Well No. 4 (Bath Wells) at Bristol.

2. King Farms Company weli No. 4, 1.9 miles east of Tullytown, depth 65 feet.

3. Starkey-Hollywood No. 1 well, 4.1 miles east of Tullytown, depth about 20 fe日t.

4. Pennsbury well No. 2, 2.5 miles east of. Tullytown, depth about 40 foet.

5. Starkey farms well No. $1,3.7$ miles east of Tullytown, depth 40 feot.

6. Starkey-Berry No: 1 well, 3.8 miles east of Tullytown, depth about 20 feet.

resiervolr. One of the largest sand and gravel dredging operations in the Commonwealth is being carried on by the Warner Co. in the middle of the valley plain near Tullytown. Penn Manor and Van Sciver Lakes, which were produced by this dredging, are shown on plate 1. However, not all the valley-plain deposits contain such high percentages of sand and gravel at shallow depth as found on the Warner property. Figure 10 indicates this variability of both depth and lateral extension.

Nevertheless, the 34 square miles underlain by the unconsolidated sediments of the valley plain constitute a large ground-water reservoir essentially filled with water which at present is only lightly developed. The relatively high porosity (porhaps 25 percent) of the sand and gravel make possible the temporary storage of billions of gallons of ground water. The normal volume of water stored in Van Sciver and Penn Manor Lakes, comprising a total area of 1.42 square miles, is approximately 1,150 million cubic feet, or nearly 9,000 million gallons.

In 1948 the Geological survey made a geophysical study of the sand-and-gravel areas in order to ascertain the thickness of the sediments and to ostablish in general terms the relative amounts of sand, gravel, and clay. Figure 11 is a map showing, by contours, the configuration of the floor, as determined from the geophysical survey and data on borings and wells. The thickness of the unconsolidated sediments can be computed as the difference botween the surface altitude at any one point and the corresponding bedrock surface altitude as shown by the contours.
A striking feature of the geology of the area is the valley-like depressions in the bedrock shown in figure 10. These depressions are the result of prehistoric river erosion. The identification of former river channels which are filled with sands and gravels is of practical importance, for such areas normally contain the greatest thickness of the most permeable material and consequently provide the greatest jields to wells.

Water lovels in wells and lakes, except where lowered locally by heavy pumping, generally are between 5 and 20 foet bolow the average land surface, and are roughly at river level. The ground-water surface slopes gently toward the river except in time of flood. The river-surface altitude is the controlling factor influencing ground-water levels. The saturated thickness of the sands, gravels, and clays may be approx1mated at any point by subtracting the altitude of the bedrock surface shown in figure 11 from the altitude of the river surface.

\section{Possible Use of Wells for Developing Surface- Water Infiltration}

In many areas throughout the country, where perennial streams are underlain by highly permeable materlals, the use of wolls for inducing infiltration from the river has been found practical. This procodure has boen particularly successful in the Ohio River Valley, a velley cut in bodrock and then partialiy filled with pormeable sand and gravel deposits originating in the glaciated headwater areas. The geology of the shallow sand and gravel materials in southeastern Bucks County indicates a similar 


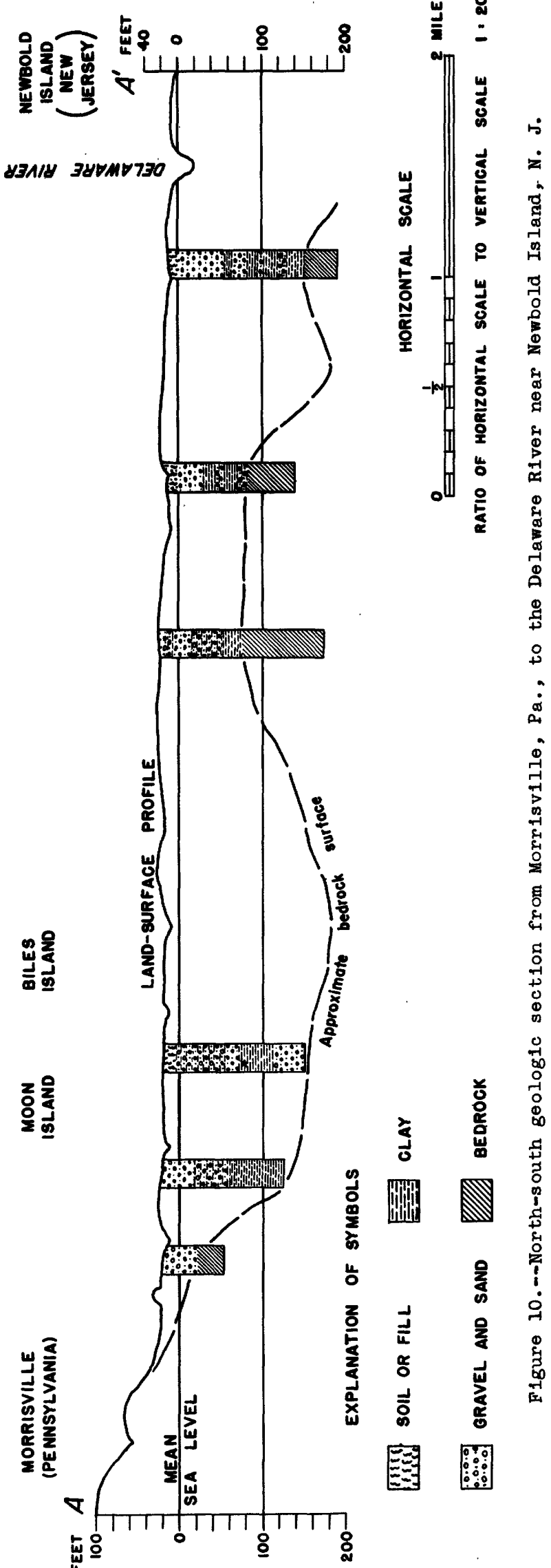

history and equally favorable ground-water conditions.

The Delaware has $26 \mathrm{miles}$ of frontage in the area. It is probable that along parts of this frontage the permeablilty of the river bed and of the sediments near the river is great onough to permit rapld inflow of river water to wolls near the river's edge. In order to induce such infiltration it is necessary to reverse the flow of ground water, which normaliy is from the valley piain to the river. This reversal of flow is accomplished by pumping heavily enough to lower the ground-water surface bolow river level. As a result of such drawdown, ground water flowing to points of natural discharge in the river will be intercepted by the well, and at the same time water will be caused to move from the river toward the well. Similar favorablo conditions oxist for inducing infiltration from the lakes in the dredging basins and from the several small tributaries to the Delaware River where they cross its valley plain. The principle of reversing the natural ground-water gradient and inducing infiltration from surface water is 1liustratod in figuro 12. The advantages of such installations are the perennial source of recharge from surface water and a somewhat greater yleld than that from wells farther from the source of recharge. Disadvantages of wells relying on induced infiltration are fiuctuations in the temperature and quality of the ground water in response to changes in surface-water temperature and quality. The experience with such installations in other river valleys, however, has indicated that wells drilled on the banks or even through the beds of rivers generally yield water having a maximum temperature at least $15^{\circ}$ lower than the maximum river-water temperature. Comparison of chemical analyses of the water from such wolls and from the adjacent river indicates that, soon after pumping begins, the well water bocomes similar in chemical character to the river water. However, all suspended matter is normally removed in the natural filtration taking place betweon river bed and well. It appears, also that some objectionable tastes and odors are removed from the river water during the filtration process, and that the natural filtration assists in the removal of harmful bacterlal organisms.

In addition to the geologic evidence favorable to induced river infiltration, there are hydrau11c, chemical, and thermometric evidences that some of the existing wells, particularly in the Bristol area, are fed in part by seopage from the Delaware River. The temperature of one such well has been reported as high as $72^{\circ} \mathrm{F}$; ; such a temperature could not reasonably be explained by anything other than infiltration of river water. In chemical quality some well waters are very similar to Delaware River water.

\section{WATER IAWS}

All agencies or private interests contemplating any development involving natural surface waters should first communicate with the proper State agency at Harrisburg, $\mathrm{Pa}$. The Commonwealth of Pennsylvania has laws that relate to its natural surface waters. The Pennsylvania Department of Forests and Waters and the Water and Power Resources Board have jurisdiction over the construction of dams and other obstructions that might change in any way the course, velocity, or cross section of any stream. They are also empowered to allocate all surface waters for public supply. The Pennsylvania Department of Health and the Sanitary Water Board administer water laws that relate to sanitation and pollution. 


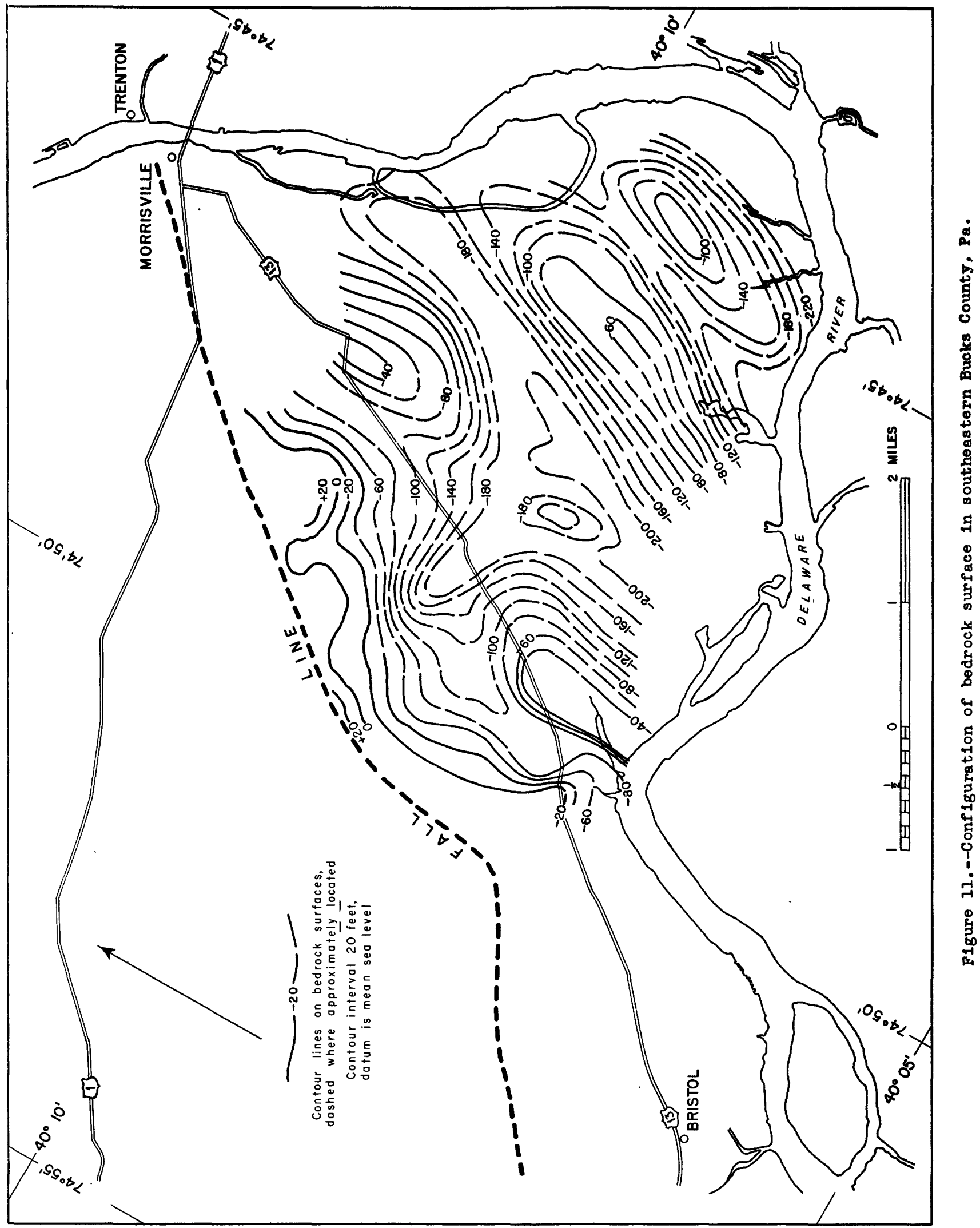




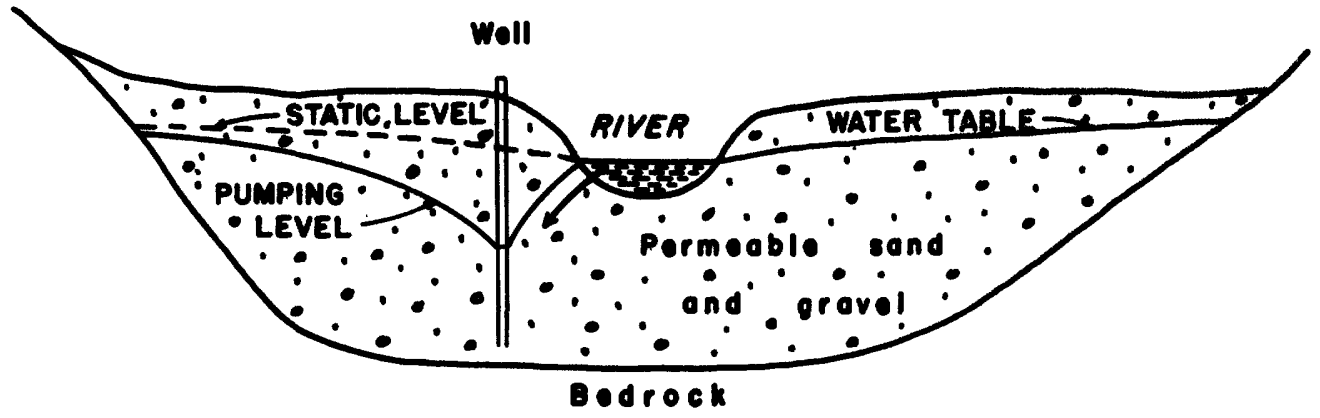

Figure 12.--Sohematio oros seotion of a river valley showing infiltration of river water to nearby well

The Delaware Rivar has been classified as a navigable stream by the Federal Government. Consequently, dam and bridge projects are also subject to the jurisdiction of the Corps of Engineers. Furthermore, the Delaware River is a state-boundary stream, and water projects of an interstate nature make necessary concurrent legislation in each state.

New Jersey is the only one of the three Delaware Basin States heving state-wide laws pertaining to ground water. Similar legislation may be enacted soon in Pennsyliania and New York.

\section{SUMMARY}

If any region is to attain industrial greatness, water must be avallable in sufficient quantities and of proper quality to satisfy all domestic and Industrial needs. Southeastern Bucks County appears to meet these requirements satisfactorily.

The Delaware River is the principal source of water supply for large industrial users in the region, although several other streams could lend themselves to small withdrawals. The supply of Delaware River water avallable is far in excess of the present demand. Even with increased industrial development it appears safe to assume that favorable water conditions will continue for many years.

Delaware River water passing the area is of satisfactory quality for most industrial uses but is subject to some pollution. However, this condition should be materially improved before long, now trat the Delaware Basin'States have undertaken a vigorous campaign to reduce the pollution load of the river by requiring municipalitios and industries to install or improve facilities for treating sewage.

The present use of ground water in the area is only a small fraction of the potential supply. Large undeveloped quantities of ground water are present underneath the broad alluvial plain of southeastern Bucks Couhty. Abundant perennial supplies can be developed by wells that are located along the Delaware River so as to induce infiltration from the river.

The chemical quality of the ground water is generally satisfactory excopt for excessive iron and nitrate content in some lacalities. The ground water is relatively constant in temperature and is cool in the summer, making it well suited for a coolant.

The water resources of an area are continually changing. Construction of reservoirs, the growth of cities and industries, the change in indus trial processes, and the addition of new industries all affect the quantity and quality of water available. Reduction of domestic and industrial pollution improves the quality of the water. The U. S. Geological Survey and its cooperating agencies are continually collecting hydrologic data to permit evaluation of current water conditions within the area. 
Inquiries relating to current water-resources information may be addressed to the following offloers:

Quality of water:

Ph1ladelphia

Distriot Chemist

U. S. Geological survey Bullaing 720

U. S. Haval Sh1pyard

Philadelphia 12, Pa.

Ground water:

Phlladelphia

District Geologist

U. S. Geolog 1cal Survey 18th St. and Parkway

Surface water:

Ph1ladelph1a $3, \mathrm{~Pa}$.

\begin{abstract}
Harrisburg
\end{abstract}
Distriot Englneer

U. s. Geologleal Survey

P. O. Box 42I

Harr 1s burg, $\mathbf{P a}$.

Trenton

\section{District Engineer}

U. S. Geolog1cal Survey

P. 0. Box 967

Trenton, N. J.

Topographic maps:

\section{Director}

U. S. Geological Survey

Washington 25, D. C.

More detalled information on various aspects of water resources in southeastern Bucks County may be obtained from the following selected references.

\section{Selected references}

Bascom, F., and others, 1909, Trenton follo of geologic atlas: U. S. Geol. Survey Geologic Atlas of the United States, follo 167.24 follo pp., 2 quadrangle maps, 1 columnar-section sheet.

Describes geology in deta1l and summarizes the mineral and water resources of the Trenm ton (30-minute) quadrangle, which includes southeastern Bucks County, with maps of topography and areal geology.

Grover, N. C., 1937, Floods of March 1936, Part 2, Hudson River to Susquehanna RIver region: U. $S$. Geol. Survey Water-Supply Paper 799,380 pp. 49 figs., 12 pls. (offset.)

Describes flood conditions and related meteorologic and hydrologic data, including bihourly discharges of the Delaware RIver at Morrisville, Mar. 8 to 25,1936 , and maps of flood conditions for the whole river basin.

Hall, G. M., 1934, Ground water in southeastern Pennsylvanias Pennsylvania Dept. of Internal Affalrs, Topog. and Geol. Survey, 4th ser., Bull. W2, 255 pp., 7 figs., 7 pls.

Describes geologic and ground-water conditions by water-bearing formations anc. by county areas, Including data on 15 wells in southeastern Bucks County, and an areal geologic map on a scale of I inch equals 6 miles.

Hartwe11, 0. W., 1929, Surface water supply of New Jersey, to sept. 30, 1928: New Jersey Dept. of Cons. and Devel., Buil. 33, 301 pp., il pls. Contains dally discharge records, including the Delaware River at Morrisvilie, 1913-28, and photograph of the gaging station.
Hartwell, 0. H., 1936, Surface water supply of. New Jersey, oct. I, 1928 to Sept. 30, $1934:$ New Jersey Water Polloy Comm. Speclal Report 5,253 pp., 8 f1gs. (offset.).

contalns dally discharge records, including the Delaware River at Morr1sv11.1e, 1828-34, and graph showing daliy discharge during lás.

Hartwel1, O. H., 1844, Surface water supply of New Jersey, Oct. 1, 1934 to Sept. 30, 1940: New Jersey Water Policy Comm. Special Report 8, 444 pp., 4 figs. (Offset.)

Contalns daliy discharge records, Including the Deiaware R1ver at Morrisvilie, 1834-40.

Malcolm Plrnie Engineers, and Albright and Friel, Inc., 1950. Report on the ut1lization of the waters of the Delaware R1ver Basin for the Interstate Commission on the Delaware River Basin, 154 pp., 19 figs., 37 pls. Describes needs of, problems of, and detalled project recommendations for the river basin, based primarily on increasing the minlmum flow of the Delaware River at Morrisville to at least 4,000 cub1c feet per second, and at the same time providing larger water supplies for the bas in states.

Mangan, J. W., 1940, Natural water losses from Pennsylvania dra inage bas Ins: Pennsylvania Dept. of Forests and Haters, 73 pp. (Offset.) Includes summary of annual precipttation, runoff, and water loss of that part of Delaware River Bas in that is upstream from Morrisville, 1921-39, and of Neshaminy Creek upstream from Langhorne, 1935-39.

Mangan, J. W., 1946, Temperatures of natural waters in Pennsylvania: Pennsylvania Dept. of Forests and Waters, $222 \mathrm{pp}$. Contains daily temperatures of the Delaware River at Morrisvilie and 40 temperatures of Neshaminy Creek near Langhorne, during water jear 1944-45.

Pennsylvania Dept. of Forests and Waters, Stream flow records of Pennsylvania, issued at intervals of 1 to 4 years for water years 1921-22 to $1940-41$.

Contains dally discharge records, including the Delaware River at Morrisville, 1822-41, and Neshominy Creek near Langhorne, 1934-4i.

Pennsylvania State Planning Board, 1847: Industrial ut1lity of water in Pennsylvania, chem1cal character of surface water, 1944-46, Pub. 17,172 pp., 9 flgs.

Contalns chemical analyses of composites of dally water samples from the Delaware River at Morrisville, water years, $1844-45$ and 184546 , and four analyses of water from Neshaminy creek near Langhorne.

Pennsylvania Water Supply Commission, 1917, Water resources inventory report, Part 3, Gazetteer of streams, 657 pp., 20 pls.

Summarizés natural, hydrographic, and artiflclal features of each of 644 principal streams, including the Delaware River and Neshaminy Creek, and also the names and dralinage areas of all minor streams.

Reglonal Planning Federation of the PhIladelphia Tri-state District, 1932, Regional plan of the Philadelphia tri-state district, 589 pp., profusely 1 llustrated.

Describes all phases of regional planning, including water supply and sanitation, for 
the region consisting of New Castle County, Del.; Mercer, Burlington, Camden, Gloucester, and Salem Countios, N. J.; and Bucks, Montgomery, Philadelphia, Chester, and Délawaro Counties, $\mathrm{Pa}$.

U. S. Coast and Goodetic Survey, 1ssuod annually, Current tablos, Atlantic Coast, North America. GIves prodicted times of slack water and times and velocitios of maximim strength of current, Including such data for the Delaware Bay entrance and conversion factors for tidal. locations along the river as far upstream as Bristol.

U. S. Coast and Goodetlc Survey, 1ssued annually, Tide tables, Atlantic Ocean, and Tido tablos, east coast, North and South Amorica. alves predicted times and helghts of high and low tides, including such data for the Delaware River at Philadelphia and conversion factors for other tidal locations alons the river as far upstream as Morrisililo.

U. S. Geologlcal Survey, issued annually (soo below), Surface water supply of the United States, Part 1, North Atlant1c slope basins.
(Offset.)

Contains da1ly discharge rocords, Including the Delaware kiver at Trenton, N. J. (Morrisv1110, $\mathrm{Pa}_{\text {.) }}$ 1913-47, and Neshaming Crook near Langhorne, 19.34-47:

\begin{tabular}{|c|c|c|c|}
\hline Vater & & Water & \\
\hline $\begin{array}{l}\text { year } \\
1913-22 \\
1922-23 \\
1923-24 \\
1924-25 \\
1925-26 \\
1926-27 \\
1927-28 \\
1928-29 \\
1929-30 \\
1830-31 \\
1931-32 \\
1832-33 \\
1933-34\end{array}$ & $\begin{array}{r}\text { Publication } \\
\text { W.s.P. } 541 \\
561 \\
581 \\
601 \\
621 \\
641 \\
661 \\
681 \\
696 \\
711 \\
726 \\
741 \\
756\end{array}$ & $\begin{array}{c}\text { year } \\
1834-35 \\
1935-36 \\
1936-37 \\
1937-38 \\
1938-38 \\
1939-40 \\
1940-41 \\
1941-42 \\
1942-43 \\
1943-44 \\
1944-45 \\
1945-46 \\
1946-47\end{array}$ & $\begin{array}{r}\text { Publication } \\
\text { W.S.P. } 781 \\
801 \\
821 \\
851 \\
871 \\
891 \\
921 \\
951 \\
971 \\
1001 \\
1031 \\
1051 \\
1081\end{array}$ \\
\hline
\end{tabular}

J. S. Geological Survey, Quality of surface waters in tho United States in 1946: Water supply Paper 1050 (In press).

W1ll contain chemical analjses of the Delaware River at Morrisvilie, 1946. 